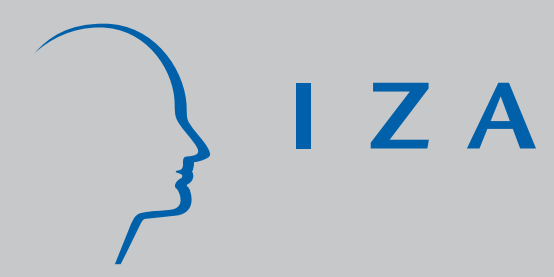

IZA DP No. 502

Immigrants' Language Skills: The Australian Experience in a Longitudinal Survey

Barry R. Chiswick

Yew Liang Lee

Paul W. Miller

May 2002 


\title{
Immigrants' Language Skills: The Australian Experience in a Longitudinal Survey
}

\author{
Barry R. Chiswick \\ University of Illinois, Chicago and IZA Bonn \\ Yew Liang Lee \\ University of Western Australia \\ Paul W. Miller \\ University of Western Australia
}

Discussion Paper No. 502

May 2002

\author{
IZA \\ P.O. Box 7240 \\ D-53072 Bonn \\ Germany \\ Tel.: +49-228-3894-0 \\ Fax: +49-228-3894-210 \\ Email: iza@iza.org
}

This Discussion Paper is issued within the framework of IZA's research area Mobility and Flexibility of Labor. Any opinions expressed here are those of the author(s) and not those of the institute. Research disseminated by IZA may include views on policy, but the institute itself takes no institutional policy positions.

The Institute for the Study of Labor (IZA) in Bonn is a local and virtual international research center and a place of communication between science, politics and business. IZA is an independent, nonprofit limited liability company (Gesellschaft mit beschränkter Haftung) supported by the Deutsche Post AG. The center is associated with the University of Bonn and offers a stimulating research environment through its research networks, research support, and visitors and doctoral programs. IZA engages in (i) original and internationally competitive research in all fields of labor economics, (ii) development of policy concepts, and (iii) dissemination of research results and concepts to the interested public. The current research program deals with (1) mobility and flexibility of labor, (2) internationalization of labor markets, (3) the welfare state and labor markets, (4) labor markets in transition countries, (5) the future of labor, (6) evaluation of labor market policies and projects and (7) general labor economics.

IZA Discussion Papers often represent preliminary work and are circulated to encourage discussion. Citation of such a paper should account for its provisional character. A revised version may be available on the IZA website (www.iza.org) or directly from the author. 
IZA Discussion Paper No. 502

May 2002

\section{ABSTRACT \\ Immigrants' Language Skills: The Australian Experience in a Longitudinal Survey *}

This paper is concerned with the determinants of English language proficiency (speaking, reading and writing) among immigrants. It presents a model of immigrant destination language acquisition based on economic incentives, exposure to the destination language, and efficiency in second language acquisition. A unique data set, the Longitudinal Survey of Immigrants to Australia, is used to test the model. This survey had three waves, at about 6 months, 18 months and $3 \frac{1}{2}$ years after immigration. The analyses are performed by wave, type of language skill and gender using probit analysis. Bivariate probit analysis is used across waves. The hypotheses are supported by the data. The bivariate probit analysis indicates a positive correlation in the unexplained component that declines with time between waves, indicating a regression to the mean in English language proficiency.

JEL Classification: J15, J61, I29

Keywords: immigrants, language skills, longitudinal survey, Australia

Barry R. Chiswick

Department of Economics (MC 144)

College of Business Administration

601 S. Morgan Street (Room 2103 UH)

Chicago, IL 60607-7121

USA

Tel.: +1 (312) 9962683

Fax: +1 (312) 9963344

Email: brchis@uic.edu

\footnotetext{
* Miller acknowledges financial assistance from the Australian Research Council.
} 


\section{IMMIGRANTS' LANGUAGE SKILLS:}

\section{THE AUSTRALIAN EXPERIENCE IN A LONGITUDINAL SURVEY}

\section{INTRODUCTION}

Around one-quarter of Australia's 19 million people were born overseas. This is the result of almost 6 million people having migrated to Australia since 1945. For much of this period the migration flows were dominated by settlers arriving from the British Isles. In more recent years migration flows from other parts of Europe and then from Asia have increased in importance. One consequence of the changing mix of settler arrivals is that Australia's population has changed from being mostly AngloCeltic to a more cosmopolitan mix of Anglo-Celtic (74 percent), Other European (19 percent) and Asian (4.5 percent). ${ }^{1}$ A major effect of this change in the make-up of Australia's population has been in language use. In 1976, for example, English was the only language regularly spoken by 91 percent of the population. In 1996, English was the only language spoken at home by 81 percent of the population. ${ }^{2}$

Like many other aspects of immigrants' adjustment to Australia (e.g., earnings, unemployment rates, citizenship), English language skills vary across immigrant groups. According to data collected in 1994, for example, 3.1 percent of immigrants from Northern Europe were not proficient in spoken English, compared to 45.8 percent from North East Asia and 67.6 percent from Eastern Europe. ${ }^{3}$

Information on the language skills of immigrants has implications for settlement policy. Should immigrants from a particular linguistic origin be encouraged to settle together or to be disbursed? Should language training facilities merely be made available or heavily subsidized? Do the assimilation costs of immigrants, to themselves and to the public, vary by type of visa, including visas based on skill, family ties or refugee status?

\footnotetext{
${ }^{1}$ Department of Immigration and Multicultural and Indigenous Affairs, Fact Sheet Number 4
}

${ }^{2}$ A language question (whether the person could read and write) was first asked in an Australian Census in 1921. In the 1933 Census there was a question on whether the person could read and write a foreign language if unable to read and write English. A question on the language regularly used was included in the 1976 Census. Since then questions on proficiency in spoken English and on languages spoken at home have been used.

${ }^{3}$ The source for these statistics is the Longitudinal Survey of Immigrants to Australia described in Section III. 
Despite the obvious importance of the language skills of immigrants to Australia, there have been few systematic analyses of these skills. Notable exceptions are Evans (1986) and Chiswick and Miller (1995)(1996)(1999). These studies demonstrate that immigration at an older age is associated with lower fluency in English, while English speaking skills are greater the longer the duration in Australia and among the better educated. English speaking skills have also been shown to vary with the linguistic distance between the immigrant's mother tongue and English, with the geographic distance between the country of origin and Australia, with exposure to English in the origin and with refugee status. The ability to avoid using English also matters, with the greater the extent of origin language newspapers and the percentage of the population in the region in which the immigrant lives that speaks the immigrant's mother tongue being associated with poorer spoken English.

A primary focus of this research has been on the improvement in English speaking skills with duration of residence. This generally has been interpreted as an immigrant adjustment phenomenon. However, the research into immigrant earnings, which draws attention to the potential for pure adjustment effects to be confounded with cohort effects (see Chiswick (1980), Borjas (1985)) suggests caution should be exercised when making longitudinal inferences on the basis of cross-sectional studies. Inferences on immigrant adjustment are best made using longitudinal data.

This paper provides a study of immigrant language skills using a reasonably unique data set that permits a cohort of settler arrivals to be followed for the first $3 \frac{1}{2}$ years of their residence in Australia. The survey contains information on reading and writing skills that can also be analysed to complement the research into the determinants of immigrants' speaking skills in Australia by Evans (1986) and Chiswick and Miller (1995)(1996)(1999). The structure of the paper is as follows. A model of dominant language skills is outlined in Section II. Section III outlines salient features of the Longitudinal Survey of Immigrants to Australia that provides the basis for the empirical sections of the paper. In Section IV some basic crosstabulations of English skills by region of birth are presented. Section V contains econometric estimates of the model developed in Section II. Most of this section is devoted to the study of English speaking skills at various durations of residence in Australia. The findings in relation to English reading and writing skills are broadly similar to those presented for speaking skills, and so are covered in a more cursory manner. Section VI contains analyses of the developments of English speaking, 
reading and writing skills based on a bivariate probit model. By linking the information on English skills collected for the same individual at two separate points in time, inferences can be made as to the role of unobserved factors on English proficiency. Given the low explanatory power of some of the cross-section models, it is apparent that unmeasured or unobserved factors are of major importance in this type of analysis. Concluding comments are provided in Section VII.

\section{A MODEL OF LANGUAGE SKILLS}

The model of language skills that forms the basis of the studies by Chiswick and Miller (1995)(1996)(1999) relates the acquisition of English speaking skills to three broad sets of factors, namely economic incentives, efficiency in language acquisition, and exposure to English prior to and after migration. ${ }^{4}$ This model is also applicable to immigrants' acquisition of English reading and writing skills. Hence, an immigrant's proficiency in either English speaking, reading or writing skills (LANG) may be modelled as

$$
\mathrm{LANG}=\mathrm{f}(\text { economic incentives, efficiency, exposure })
$$

Economic incentives for the acquisition of English skills among settler arrivals in Australia depend on the labour market (i.e., the wage, training and employment increments) and consumption (i.e., lower search costs for favourable prices and higher quality goods and services) benefits expected to be associated with these skills, and the length of time over which these benefits are expected to accrue. These advantages have proven to be very difficult to incorporate into empirical studies because of the problems in determining the economic gains associated with improvements in English skills for specific individuals. While the LSIA follows immigrants for about $3 \frac{1}{2}$ years and hence changes in language skills can, in principle, be linked to changes in wages for some individuals, the endogeneity of the wage change variable in the model of language skills would still need to be addressed. There are two difficulties in accommodating this endogeneity. First, the changes in wages are available only for

\footnotetext{
${ }^{4}$ This approach has been used in empirical studies of English-language skills among immigrants in the United States (Chiswick and Miller (1992)(1998a)) and Australia (Chiswick and Miller (1995)(1996)(1999)), Hebrew-language skills in Israel (Beenstock (1996); Chiswick (1998)), French- and English-language skills among immigrants in Canada (Chiswick and Miller (1992)(1994)(2001)) and language skills among immigrants in Germany (Dustmann (1994)).
} 
individuals who change language state (e.g., they change from "not fluent in English" to "fluent in English"). Second, the data sets lacks variables that might be appropriate identifying instruments. These limitations preclude an adequate treatment of the endogeneity inherent in the model.

The expected length of time over which the wage and other employment and consumption gains are to be realised is also likely to be an important factor. Information on whether immigrants expected to leave Australia permanently at some future date can be used to capture this set of influences. Birthplace can also be used as a measure of the incidence of return migration, since origins differ in the extent of permanent and sojourner migration. Finally, the geographic distance of the country of origin from Australia is also relevant here as greater geographic distance is expected to be associated with a lesser expectation of return migration and hence a greater incentive to invest in destination specific skills, including language skills.

Efficiency refers to the extent to which a given amount of exposure to English produces language proficiency. It has been shown in numerous studies that proficiency is enhanced by a higher level of education and by migration while young (see Long (1990), Service and Craik (1993) on the age effects in language attainment). In comparison to the studies by Chiswick and Miller (1995)(1996)(1999) and Evans (1986), the age at migration effects may have a different interpretation in some of the analyses presented below. The recent settler arrivals that provide the information base for the empirical section of the study were first interviewed after about six months in Australia. This may be too short a period for the age (at migration) variable to record the impact of the speed at which English can be learned after migration. A second factor that the age variable may reflect is the learning of English at school in their origin country among younger immigrants, which would be reflected in a measure of language skills recorded at or just after migration.

After the recent arrivals have spent more time in Australia, however, the age effects will be more likely to incorporate the efficiency factors discussed to date in the literature. Examination of the changes in the impact of age on language attainment in the data obtained in the subsequent interviews (at $1 \frac{1}{2}$ and $3 \frac{1}{2}$ years of residence in Australia) will provide information on the extent to which age at migration reflects differences in the speed with which English language skills can be acquired. This is a benefit from being able to follow the same arrival cohort through time. 
Another efficiency variable is the extent of the difference between the origin language and English. It should, for example, be more difficult for a Chinese speaker to learn English than it is for a French speaker to learn English because the difference between the languages is that much greater. That is, the "linguistic distance" between Chinese and English is greater than that between French and English. The greater the linguistic difference between English and the origin language, the lower would be the efficiency of an immigrant for learning English. Chiswick and Miller (1998a) developed an index of "linguistic distance" based on the degree of difficulty that Americans who are native English speakers have learning foreign languages. It is developed from a set of language learning scores (LS) presented in Hart-Gonzalez and Lindemann (1993). A low value of the score is indicative of a high degree of difficulty (e.g., Cantonese $\mathrm{LS}=1.25)$ and a high value is indicative of a low degree of difficulty (e.g., Dutch LS = 2.75). Following Chiswick and Miller (1998a), linguistic distance is entered into the estimating equation as the reciprocal of the language score, that is, $L D=1 / L S$. Thus, a higher value for $L D$ means a greater distance between English and the origin language.

Exposure has three dimensions. These are: exposure prior to migration, time units of exposure in the destination country, and the intensity of exposure per unit of time in the destination.

Two measures of exposure prior to migration are considered. The first of these is constructed from information on the extent of cross country/culture contact in the country of origin. The hypothesis is that immigrants from countries where there is a lot of contact of this nature would be more likely to have been exposed to English, or at least have a relatively favourable disposition towards other cultures that may be associated with a greater preparedness to learn English.

A second variable is given by whether the immigrant visited Australia prior to migrating. Visits to Australia prior to migration could reflect two factors. On the one hand, the immigrant would be exposed to English during such visits. On the other hand, the visits could be indicative of a greater degree of planning for the migration. Accordingly, it is expected that immigrants who visited Australia prior to migrating would have English skills superior to the skills of those who did not visit Australia. While this influence should hold for any immigrant-receiving country, it should be particularly relevant for immigrants in Australia, given the distances involved in international travel. 
The number of years since migration provides a measure of time units of exposure in Australia. While this variable plays a key role in cross-sectional studies, it is not a direct consideration in the study of language skills in a single arrival cohort since duration is the same for all observations. As noted in the Introduction, however, by examining the same cohort of arrivals at various lengths of residence in Australia, it will be possible to determine whether improvements in language skills with duration in cross-sectional studies reflect cohort or true longitudinal effects.

The intensity of exposure per unit of time in Australia is more complex. It will depend on the characteristics of the person's home and location. The home environment is measured in most analyses through variables for the number and ages of children, and for the birthplace or language skills of the spouse. In the LSIA there is information both on the family structure and on whether children live with their parents. Moreover, the survey contains details on whether other people who were part of the "migrating unit" live with the respondent. Hence, the following variables may be included in the estimating equation that corresponds to the language model: whether a spouse who was part of the migrating unit is present in the household (MUS); whether a spouse who was not part of the migrating unit is present in the household (OS); whether there are children in the household (KIDS); whether other relatives who gained approval to migrate to Australia as part of the Principal Applicant's migration application are present in the household (MUR); whether other relatives are present in the household (OR).

The information on the immigrant's living arrangements can be complemented with information on the main reason the immigrant chose his/her State of initial settlement. Where "family/friends" is the main reason for the choice of location, it is expected that the immigrant will have access to an ethnic network. The availability of this ethnic network can reduce the exposure to, and practice in using, English, and hence reduce proficiency.

The characteristics of the person's location have been typically captured by a "minority-language concentration" variable. This is generally measured as the percentage of individuals living in the immigrant's region of residence that speaks the same minority language as the immigrant. A similar variable can be constructed using the birthplace characteristics of the population of the region of residence, and this is the approach followed in this study. As there are obvious links between birthplace and language, especially when disaggregated birthplace data are used 
(around 50 birthplaces are used in the current analysis) this should not be viewed as a limitation. $^{5}$

In a region where a high percentage of individuals are from the same birthplace, and hence many will speak the same minority language as the immigrant, the costs of not knowing the dominant language, or the benefits of learning the dominant language, are presumably decreased. These effects arise from the ability to communicate in consumer, labour market and social activities in the immigrant's mother tongue. Moreover, since second language skills improve with experience using the language, improvements in English language skills are retarded by using the mother tongue.

The empirical counterpart to equation (1) used in this research is:

LANG $=\mathrm{f}$ (visa category, age, education, gender, birthplace, preparation for migration, expected duration in destination, family structure, prevalence of origin language in region of residence, linguistic distance, distance of origin country).

The approach to estimation is as follows. First, a model is estimated that includes only variables for visa category, educational attainment, age at migration, gender, the main reason for choosing the State settled, the family structure and birthplace. The coefficients on the birthplace variables in this specification will record the country fixed effects. Variables that are related to birthplace, such as the distance between the origin country and the place of residence in Australia, linguistic distance, minority language (birthplace) concentration, the cross country/culture contact in the former home country, the expectation of return migration and whether the origin country was a former British colony, are then entered into the estimating equation in place of the birthplace variables. A final equation includes both the birthplace variables and the set of variables that is held to be related to the country fixed effects. (See Chiswick and Miller (2001) for an application of this methodology to the study of the language skills of immigrants in Canada.) All variables are defined in Appendix A. This appendix also contains means and standard deviations for the variables.

\footnotetext{
${ }^{5}$ Where individuals do not report speaking a language other than English, a minority language concentration variable is often constructed using details on place of birth, adding to the similarity of the two variables.
} 


\section{THE LONGITUDINAL SURVEY OF IMMIGRANTS TO AUSTRALIA}

The analyses reported below are based on the Longitudinal Survey of Immigrants to Australia (LSIA), a longitudinal study of immigrants who received their visas before entry into Australia. The population represented in the sample is all Principal Applicants, aged 15 years and over, who arrived in Australia as offshore visaed immigrants in the two-year period of September 1993 to August $1995 .{ }^{6}$

In the LSIA immigrants were interviewed three times. The first interview took place approximately five or six months after arrival, the second interview one year later and the third interview a further two years later. The first, second and third interviews commenced in March 1994, March 1995 and March 1997, respectively.

Principal Applicant immigrants selected for interview were those who settled in State and Territory capital cities (including major urban centres close to capital cities such as Newcastle and Wollongong) as well as Cairns. Only 4 to 5 percent of the total of Principal Applicant immigrants are excluded from the coverage of the survey because they live outside of these areas.

The final LSIA sample was 5192 Principal Applicant arrivals. This represents about seven percent of all Principal Applicants who arrived in the two-year survey period. The population from which the sample was selected at random was stratified according to visa eligibility category ${ }^{7}$ and also by about fifty regions or countries of birth.

A feature of the sampling frame for the LSIA is that Principal Applicants in smaller States and Territories were over-sampled. Weights are available to adjust for this. These estimation weights were modified to account for sample attrition between the first and third waves of the survey. ${ }^{8}$ As noted by Murphy (1997, p.66), the LSIA

\footnotetext{
${ }^{6}$ The Principal Applicant is the person upon whom the approval to immigrate was based. Excluded from the scope of the survey are New Zealand citizens and those granted a visa while resident in Australia.

7 The five main visa categories are Preferential Family, Concessional Family, Business Skills and Employer Nomination, Independent, and Humanitarian.

8723 Principal Applicants were lost from the sample by the time of the second interview (attrition rate of 13.9 percent). There was a further loss of 717 Principal Applicants by the time of the third interview (i.e., total attrition of 27.7 percent of Principal Applicants between the first and third waves).
} 
data should be used in weighted form so that the sample reflects the total population of immigrants arriving in the reference period. All analyses in this study use relevant estimation weights. Experiments show that the use of weights has a reasonably modest effect on statistical results.

The LSIA data have been used by a number of authors. Murphy (1997), for example, has studied the initial location decisions of immigrants using the first wave of the survey. Cobb-Clark (2000) has used the data to examine the links between visa class and labour market outcomes in the first few years of residence in Australia. The following analyses expand the use of the LSIA data to cover language issues and also add a further dimension by augmenting the data with information from the 1991 Australian Census of Population and Housing and other data sets.

\section{THE DISTRIBUTION OF LANGUAGE SKILLS}

The LSIA contains a considerable amount of information on language skills. In the first wave of interviews, individuals were required to provide details on the languages they speak well, the main languages they speak at home in Australia, and the languages they speak the best. Individuals whose best spoken language was not English (generally individuals from non-English speaking countries) had to selfassess their English speaking, reading, and writing skills.

Table 1 lists information on English speaking, reading and writing skills by region of birth six months after arrival in Australia. The sample is restricted to those aged 15 to 64 years, and excludes immigrants from the main English speaking countries. ${ }^{9}$ These restrictions are imposed to permit a focus on the group for whom the decision concerning the acquisition of English skills is most acute.

The categories of English speaking skills collected in the LSIA permit five levels to be distinguished: (i) speaks English only or, if a language other than English is spoken, English is spoken best (referred to as "English best"); speaks a language other than English best and speaks English (ii) very well; (iii) well, (iv) not well; (v) not at all. In Table 1 the first three categories (denoted "proficient") are distinguished from the remaining categories (denoted "not proficient").

\footnotetext{
${ }^{9}$ The main English speaking countries distinguished in this analysis are the UK and Ireland, Canada, South Africa and the US.
} 
Five levels of English reading (writing) skills are distinguished in the LISA: (i) English best (or English only); Speaks a language other than English best and reads (writes) English: (ii) Very well; (iii) Well; (iv) Not well; (v) Not at all, or does not speak English at all. ${ }^{10}$ In Table 1 the first three categories (denoted "proficient") are distinguished from the remaining categories (denoted "not proficient").

According to the data presented in Panel A of Table 1, 51 percent of immigrants were proficient in spoken English six months after they arrived in Australia. The immigrants who are most likely to be proficient in spoken English are from Northern Europe, Western Europe and Southern Asia (96.9 percent, 95.3 percent and 80.6 percent, respectively). Birthplace groups with rates of proficiency in spoken English around the sample mean are North Africa, North East Asia, South East Asia and South and Central America. Recent arrivals from the USSR and the Baltic States, Eastern Europe, the Middle East and Southern Europe have relatively low rates of proficiency in spoken English (proficiency rates of between 29 and 39 percent).

The second column of Panel A of Table 1 shows the rate of English reading proficiency among recent arrivals is 62 percent, 11 percentage points higher than the rate of proficiency in spoken English. Immigrants from Southern Asia, Western Europe and Northern Europe also have high rates of English reading proficiency, of around 90 percent. Between 70 and 77 percent of immigrants from North Africa and North East Asia are proficient at reading English, while the rates of English reading proficiency among recent arrivals from South and Central America, the USSR and the Baltic States, South East Asia and Eastern Europe are between 50 and 60 percent. The lowest rates of English reading proficiency are recorded by immigrants from the Middle East and Southern Europe (47.8 percent and 37.3 percent, respectively).

Around 54 percent of all recent arrivals can write English proficiently according to the data listed in the third column of Table 1 (Panel A). This rate of proficiency is comparable to that for spoken English. The highest rates of English writing proficiency are recorded among immigrants from Southern Asia, Western Europe and Northern Europe (proficiency rates of between 84 and 88 percent). North African and North East Asian immigrants also have rates of English writing

${ }^{10}$ Information on English reading and writing skills was not collected where the individual could not speak English at all. It is assumed that these individuals would not be able to read or write English. 
proficiency above average (proficiency rates of between 60 and 66 percent). There are, of course, several birthplace groups with rates of English writing proficiency slightly below the sample average, namely South East Asia, South and Central America, and the USSR and the Baltic States (proficiency rates between 42 and 51 percent). The remaining birthplace groups (namely, the Middle East, Eastern Europe and Southern Europe) have relatively low rates of English writing proficiency (proficiency rates of between 26 and 38 percent).

Panel B of Table 1 lists information on English proficiency at the time of the wave one interviews for the subset of the wave one interviewees who were also interviewed in wave 2. The purpose of this presentation is to provide an indication of the impact of sample attrition on the proficiency rates that are the focus of the study. There are generally only minor differences between Panels A and B, although it is noted that there are several cases of differences of proficiency rates of the full sample (Panel A) and the sub-sample (Panel B) of up to two percentage points (e.g., USSR and the Baltic States, North East Asia). The aggregate proficiency rates are, however, very similar in the two sets of data presented. This, and the associated absence of any systematic pattern to the differences between Panels A and B, suggest that attrition bias will not have a major impact on the analysis. This conclusion carries over to the comparison of the data in Panel $\mathrm{C}$ with the data in the other two panels of Table 1. The data in Panel $\mathrm{C}$ are the English proficiency rates at the time of the wave one interview for the subset of the wave one interviewees who were also interviewed three years later, in wave 3 of the survey.

Tables 2 and 3 present information similar to that contained in Table 1 for the second and third waves of the survey. As discussed above, there is a one-year gap between the first and second interviews (i.e., between the information in Tables 1 and 2) and a two-year gap between the second and third interviews (i.e., between the information in Tables 2 and 3).

A comparison of the information for wave 1 and wave 2 shows that the mean rates of English speaking and reading proficiency both increased by about 10 percentage points over the one-year period under review, while the rate of English writing proficiency increased by five percentage points. These appear to be quite impressive increases for such a short time period. The proportions of immigrants who speak, read and write English proficiently rise from the first wave to the second wave for all birthplace groups, except for Northern Europe. This holds even when the wave 
one group is limited to the same individuals as in wave 2 (compare Panel A of Table 2 and Panel B of Table 1).

For Northern European immigrants, the proportion with proficient writing skills fell by a modest 2 percentage points from the first to the second waves. This change is not of concern as previous analyses have shown that English skills can "deteriorate" among some groups. See, for example, Chiswick and Miller (1998b) who report that up to 15 percent of a group of legalized aliens in the US who reported that they could read or speak English in specific situations one year indicated that they could not do so three years later. The extent to which this is a true deterioration or a result of a change in the respondent's frame of reference or reference group cannot be discerned in these data.

Panel B of Table 2 contains information on the proficiency rates at the time of the wave 2 interviews of the subset of the wave 2 interviewees who were also interviewed two years later in the third wave of interviews. Comparison of Panels A and B of Table 2 shows there is little evidence of systematic differences in the rates of proficiency, suggesting that attrition bias will not be a major factor in the detailed analyses of English skills presented in the next section.

The Table 3 data show that over the two-year period between the second and third interviews, the overall rate of proficiency in spoken English increased by only 6 percentage points, while the rates of proficiency in reading and writing English increased by only 3-4 percentage points. This suggests a diminishing rate of acquisition of English skills with duration of residence in Australia, which is consistent with the results from cross-sectional studies where this phenomenon is captured by a quadratic in duration of residence. The information presented in Table 3, when compared with Panel A of Table 2, indicates that for the three types of language skills, there is an increase in the proportion of immigrants who are proficient for all, except for two, birthplace groups. The proportions of North East Asian immigrants with proficient reading skills and Southern Asian immigrants with proficient writing skills appears to have decreased between the second and third interviews. However, when the comparison is restricted to the same set of individuals who were interviewed in wave three (compare Table 3 and Panel B of Table 2) these anomalies are removed. 
Having limited English skills imposes costs on immigrants and society. For example, immigrants with poor English skills will, in general, need assistance in the conduct of their usual day-to-day activities. To illustrate this, Table 4 presents a crosstabulation on the need of an interpreter by English proficiency. Individuals who do not speak English well and those who do not speak English at all were asked if they have needed to use an interpreter since they immigrated to Australia. Around 77 percent of individuals in each of these English speaking skill levels reported that they have required the assistance of an interpreter since they arrived in Australia. ${ }^{11}$

These data emphasise the common sense notion that English skills deficiencies are associated with resource costs. ${ }^{12}$ Understanding how immigrants are distributed across language skill categories, and how this distribution changes with time in Australia, is therefore an important issue.

\section{REGRESSION RESULTS}

Table 5 lists results for equations of the model for English-speaking skills estimated for a sample pooled across males and females. ${ }^{13}$ In these models the dependent variable is a binary variable that records the immigrant's English speaking skills along the lines of that used in Tables $1-3 .{ }^{14}$ Following the study of speaking skills, the reading and writing skills of immigrants are studied in an analogous manner.

${ }^{11}$ Note that the need for an interpreter will depend on the circumstances that each immigrant has faced. We cannot control for differences in circumstances in this analysis (e.g., an immigrant with very poor English skills not needing an interpreter because a family member has always looked after their interaction with Englishspeaking society).

12 There is an abundant literature for Australia and other countries that demonstrates the lower earnings of those with lower levels of speaking, reading and writing skills.

13 Appendix B contains selected estimates obtained from the separate samples of males and females. Inspection of these results reveals there is not any real advantage to a disaggregated approach.

${ }^{14}$ Ordered probability models that examine the different degrees of proficiency (e.g., "very well" versus "well" versus "not well" etc.) were also considered. The findings are very similar to those obtained from the estimation of the binary probit models. For ease of exposition only the results from the simpler binary models are presented and discussed. 
To specify the relationship between the binary dependent variable that records English language proficiency $\left(L A N G_{i}\right)$ and the set of explanatory variables described above, a probit model is used. ${ }^{15}$ Under this model, the probability of immigrant $\mathrm{i}$ being proficient in English is assumed to be given by:

$$
\operatorname{Pr}\left(L A N G_{i}=1\right)=\Phi\left(\beta X_{i}\right)
$$

where $L A N G_{i}=1$ for individuals who are proficient in English and 0 otherwise, $\Phi$ is the standard normal cumulative distribution function, and $X$ is a vector of explanatory variables. $\beta$ is the set of parameters that capture the impact of changes in $X$ on the probability.

The marginal effects from the probit model can be computed as follows. Let $X_{i k}$ be the $\mathrm{k}^{\text {th }}$ element of the characteristics vector $X_{i}$ and let $\beta_{k}$ be the $\mathrm{k}^{\text {th }}$ element of the parameter vector $\beta$. Then:

$$
\frac{\delta}{\delta X_{i k}} \Phi\left(\beta X_{i}\right)=\phi\left(\beta X_{i}\right) \beta_{k}
$$

where $\phi$ is the standard normal density function and $\phi\left(\beta X_{i}\right) \beta_{k}$ is the change in the probability in the probit model. A useful way of evaluating this is to do so at the value of the probit index $\beta X$ that solves the equation $\beta X=\Phi^{-1}(\overline{L A N G})$, where $\overline{L A N G}$ is the mean rate of proficiency for the sample and $\Phi^{-1}$ is the inverse normal cumulative distribution function. With a mean proficiency of 0.504 the appropriate value of $\phi(\beta X)$ is 0.399 . The partial effects obtained in this manner can be multiplied by 100 to give percentage point impacts. ${ }^{16}$

The specification considered in Table 5, column (1) contains the variables for visa category, age at migration, education, gender, birthplace groups, main reason for

15 The probability function used for the logit model is the logistic distribution function. Because of the close similarity of this and the normal distribution function, it does not matter much whether one uses a probit model or a logit model in the dichotomous model.

${ }^{16}$ See Amemiya (1981, p.1488) for relevant discussion. 
choosing State settled, and family structure. The prediction success rate, which serves as one useful summary measure, is 78.5 percent. Using the mean proficiency of 0.504 , the prediction success rate under random assignment is 50.0 percent. ${ }^{17}$ Furthermore, 18 out of the 23 slope coefficients are statistically significant at the 10 percent level or better. $^{18}$

The coefficient on the age at migration variable is negative. Each extra year of age at migration is associated with about a 0.3 percentage point reduction in the level of English speaking proficiency. While the direction of this impact is consistent with those reported in the literature on dominant language acquisition among immigrants, the partial effect is very small in comparison to most other significant variables in column (1). Every additional year of education, for example, leads to an increase in the level of English proficiency of 8.5 percentage points.

The birthplace coefficients fall into three groups: countries with English speaking skills superior to the skills of the Southern Europe benchmark group (the ranking from the highest to the lowest being Northern Europe, Western Europe, Southern Asia, South East Asia); countries with English speaking skills insignificantly different from the English speaking skills of the Southern Europe benchmark group (North East Asia, North Africa, and the Middle East); and countries with English speaking skills that are inferior to the skills of Southern Europe immigrants (the ranking from highest to the lowest is South and Central America, the USSR and the Baltic States, Eastern Europe).

If the main reason for choosing the State settled was family/friends, then English speaking proficiency is decreased by 7.2 percent points. This is the equivalent of just under one extra year of education, and hence is a reasonably pronounced effect. In terms of family structure, the coefficients of all variables except for "whether other relatives who gained approval to migrate to Australia as part of the Principal Applicant's migration application are present in the household" are significant. Note also that these family structure variables are negatively associated with English speaking proficiency.

${ }^{17}$ Under random assignment using the mean proficiency $(p)$, the prediction success rate is computed as $\left[p^{2}+(1-p)^{2}\right] * 100 \%$.

${ }^{18}$ All partial effects in this section are computed as $\left(0.399 * \hat{\beta}_{\Phi} * 100\right)$ where $\hat{\beta}_{\Phi}$ is an estimate of the coefficient from the probit model, and the 0.399 is computed as described in the text. 
Table 5, Column (2) presents results from the estimating equation that replaces the birthplace variables by the variables that are related to birthplace. These are the distance between the country of origin and the place of residence in Australia, linguistic distance, minority language (birthplace) concentration, the cross country/culture contact in the former home country, the expectation of return migration and whether the country of origin was a former British colony. The prediction success rate of 79.0 percent suggests that the specification in column (2) gives a slightly better description of the data than the column (1) specification. That is, socio-economic or behavioural variables that describe the characteristics of the origin country provide more explanation than using country fixed effects. ${ }^{19}$

The coefficients on the variables that are common to the specifications in Table 5, columns (1) and (2) are generally similar in sign and impact. Six of the nine variables introduced in equation (2) are significant at the ten percent level or better. The first of these is the variable for those who were originally from former British colonies. These immigrants are much more likely to be fluent in English, the partial effect indicating that they have a rate of fluency in English that is 55 percentage points higher than that of other immigrants. Clearly exposure to English in the country of origin matters. This is reinforced by the results for the more general variable for whether there was cross country/culture contact in the former home country. Immigrants who reported such cross country/culture contact have a rate of English speaking proficiency 7.5 percentage points higher than the rate of English speaking proficiency among groups that did not have such contact. Similarly, where an immigrant had visited Australia prior to the migration, and hence presumably had engaged in a relatively high level of preparation for the migration and had received relatively greater exposure to English, English speaking skills are relatively high.

A variable that is associated with a significant reduction in the English speaking skills of Principal Applicants is where there is an expectation of leaving Australia. Principal Applicants in this category are 15 percentage points less likely to

19 The predictive ability of the model is a useful summary of the goodness of fit, though caution needs to be exercised in its application (see, for example, Greene (1991), p.683). 
be fluent in English. ${ }^{20}$ This finding is consistent with the economic model of destination language skills acquisition wherein the rate of return from any investment in language skills will be lower where the benefits will be received over only a limited period.

The birthplace concentration variable is significant at the 10 percent level. The coefficient of -0.008 implies that each extra percent of the population in the postcode area of residence that is from the same country of birth as the Principal Applicant is associated with a 0.32 percentage point reduction in English speaking skills. This finding is similar to that reported in the literature on the role of ethnic enclaves in immigrant adjustment (e.g., Chiswick and Miller (1995)), revealing that at least during the initial phases of the immigrant settlement, residence in ethnic enclaves is associated with slower adjustment.

Finally, consistent with the model outlined in Section II, the coefficient on the linguistic distance variable is negative. As this is measured as the inverse of the linguistic score $(\mathrm{LD}=1 / \mathrm{LS})$, the negative coefficient implies that immigrants whose mother tongues are linguistically more distant from English are less likely to be fluent in English. In other words, if a production function for English language skills is considered, individuals with a smaller linguistic distance (a higher language score) will, due to complementarities with their existing skill base, be more technically proficient in English skills production, and hence more fluent in English, than their counterparts with a large linguistic distance (small language score).

The results presented in Table 5, column (3) are from the specification that encompasses the models presented in columns (1) and (2). There is an increase in the prediction success rate to 80.8 percent from the 78.5 percent in column (1), and 79.0 percent in column (2). There is thus a small gain from including in a single specification both the dichotomous birthplace variables to capture country effects, and the variables created in part on the basis of birthplace that have behavioural interpretations. Most coefficients in the encompassing model are similar to those in

\footnotetext{
${ }^{20}$ Information on the length of time the immigrant planned to stay in Australia was included in some specifications. Surprisingly, immigrants who planned to stay for only a short period had English speaking skills superior to those who planned to emigrate after a longer period. Likewise, information on whether the Principal Applicant actually left Australia after the survey was included in the estimating equation, with the finding that these immigrants had relatively good English speaking skills. However, without additional information on the determinants of return migration these findings are difficult to interpret.
} 
either column (1) or column (2). ${ }^{21}$ The linguistic distance variable is approximately halved in magnitude when the country fixed effects are taken into account. This occurs even though the country groupings included in the analysis are quite broad. This presumably arises due to the high correlation between the language scores and the birthplace variables (e.g., Chinese spoken by immigrants from China).

In the remainder of this section, the models presented in Table 5 are reestimated using data from waves two and three of the survey. The aim is to see how the coefficients on the explanatory variables alter with duration in Australia. As the overwhelming majority of the explanatory variables are time invariant, there is little advantage in terms of behavioural modelling to attempting to estimate panel data models of changes in English skills. The following section, however, uses bivariate probit models as a way of linking the information from the separate waves of the survey and thus providing information on the role that unobserved influences have on the development of English speaking, reading and writing skills.

Table 6 presents the estimates from the wave two and wave three data. ${ }^{22}$ The mean fluency for the wave one data was 50.4 percent, for wave two it is 59.6 percent and for wave three it is 65.5 percent. These fluency rates are computed on successively smaller samples due to sample attrition. However, the weights that are applied to the estimates are adjusted in each wave for sample attrition (on the basis of observable factors). Consequently, the growth in English speaking proficiency of 15 percentage points over the course of the three interviews should be due in most part to the development of language skills rather than be a product of sample selection bias. ${ }^{23}$

Comparison of the partial effects in the models can be undertaken when these are evaluated at the probit index that gives the mean fluency rate for each sample. ${ }^{24}$ Alternatively, the effects can be compared when multiplied by the same factor (0.399)

${ }^{21}$ Other coefficients that change materially are those for Eastern Europe, the USSR and the Baltic States, North Africa, the distance between the country of origin and the place of settlement in Australia and its squared term.

${ }^{22}$ The following sets of variables vary with time: location of residence (and the birthplace concentration variable based on this), family structure, ethnic agencies contact, and emigration. All other variables are time invariant in this sample.

${ }^{23}$ The mean fluency rates in waves one and two for the sample used in wave three are 49.0 percent and 59.1 percent, respectively.

${ }^{24}$ For wave two the appropriate adjustment factor 0.387 ; for wave three it is 0.369 . 
as used for the wave one data. The latter approach will be followed to provide a degree of standardization in the comparisons. This means also that a direct comparison of the coefficients in the probit equations will be informative.

The first feature of the comparison across waves is that the effects associated with visa categories tend to decrease with duration of residence in Australia (that is, they decrease as the analysis moves from wave one to wave two to wave three). Psacharopoulos (1979) proposes that where the effects of a screen persist over time then the screen is a strong one, while where the effects dissipate then the screen is a weak one. In the language of the screening literature, the findings for waves two and three suggest that if visa category is a screen, it is of the weak as compared to strong variety.

In comparison to the visa category variables, the impact of the age at migration variable intensifies with duration of residence in Australia. This is consistent with the argument advanced earlier that among the recent arrivals in wave one, age at migration is more likely to capture factors associated with the immigrant's background that vary across cohorts than to capture the efficiency in learning effects conventionally associated with this variable. The likelihood that English has been learned in school is one of the factors that may dominate the wave one estimates associated with the age at migration variable. As the analysis moves to waves two and three, however, the impact age has via post-migration learning effects will increase in importance. An older age at migration will be associated with a lesser efficiency in dominant language acquisition skills, and this is presumably what is reflected in the change in the age at migration coefficients, which change from -0.007 to -0.020 to -0.030 with duration of residence in Australia (see the column (1) specification), with the t-ratios increasing as well.

The estimated impacts associated with the education variable are reasonably stable across the waves of data. This is true of all specifications reported in the Tables. In other words, the English speaking skills of the better educated that were present at the time of entry persist with duration in Australia. They do not intensify. This suggests that the advantages of the better educated may be due to the learning of English prior to migration (perhaps in the schools system) rather than being due to a greater efficiency in English skills development post arrival. 
With respect to the country of birth effects, the coefficients that are significant tend to decrease in size (in absolute value). This is consistent with the effects reported for visa category. It was argued previously that the country fixed effects act as a proxy for a range of influences, including those that are included in the column (2) specification in each of the tables. As the effects of some of the birthplace-related variables intensify (see in particular the birthplace concentration variables) with duration of residence in Australia, there is a corresponding diminution of the country fixed effects.

Many of the behavioural variables included in the column (2) specification exhibit patterns with duration of residence that are open to clear interpretation. ${ }^{25}$ The variable for whether the immigrant had visited Australia prior to migration declines in importance with duration in Australia. This indicates that the longer the immigrant resides in Australia, the less important will be pre-immigration experiences. A similar pattern is evident in the estimated impact associated with the "Former British Colony" variable. Both variables will reflect a higher degree of exposure to English prior to migration. Thus, the positive influence of the pre-immigration exposure appears to fade into the background with increases in duration of residence in Australia.

The negative effect on English speaking skills of having family and/or friends as the main reason for choosing the State settled intensifies with duration of residence in Australia. This post-immigration effect is intuitively reasonable. Immigrants who settle among family and/or friends are afforded a greater degree of protection from having to learn English compared to immigrants who settle in a particular State for other reasons. ${ }^{26}$ This variable, which is measured on an individual basis, is open to the same interpretation as the birthplace concentration variable that is measured on a group basis. Hence, it is observed that the impact of the birthplace concentration variable doubles between wave one (coefficient of -0.024) and wave three (coefficient of -0.048). This may be reflective of a compound effect over time: the language skills of those outside birthplace concentrations develop in a cumulative manner over time. Accordingly, the gap between the language skills of the residents of immigrant

\footnotetext{
${ }^{25}$ A variable which does not display a pattern across the waves of the data is the cross country/culture contact in the former home country variable.

${ }^{26}$ The most frequently given reasons for the choice of State are "spouse/partner lived here", "family living here", and "job opportunities".
} 
neighbourhoods and those who live outside such neighbourhoods will widen with duration of residence in Australia.

One variable that was significant in the wave one analyses but which is insignificant in the equations estimated for waves two and three is the measure of linguistic distance. The insignificance of the linguistic distance variable in the two later waves of the Longitudinal Survey is consistent with findings reported by Chiswick and Miller (1999). There it is reported that while a linguistic score variable was significant in some equations, it was insignificant once country of origin was held constant. In comparison, in research conducted into English language proficiency among immigrants in the United States, the linguistic distance variable is highly significant (Chiswick and Miller (1998a)). It is also significant in analyses conducted for Canada (see Chiswick and Miller (2001)).

The physical distance variables evolve in an appealing manner. In the wave three data, where the immigrants have lived in Australia for $3 \frac{1}{2} 2$ years, the estimated relationship is positive over distances greater than 8,000 kilometres (this is approximately the distance between Sydney and Rangoon, Burma). This compares with the negative relationship for distances greater than around 12,000 kilometres (this is approximately the distance between Sydney and Tehran, Iran ) in the wave one data. The physical distance variable is expected to reflect some of the effects of a smaller probability of return migration, which itself declines with distance. A positive relationship has been reported for the US (see Chiswick and Miller (1998a)) and for Canada (Chiswick and Miller (2001)).

Finally, the family structure variables are measured with respect to the specific circumstances that prevail at the time of each wave of the survey. The main change that will occur will be marriage to Australia-born spouses (which affect the "Other Spouse" variable), greater numbers of Australia-born, and by definition young, children (which will affect the "KIDS" variable) and changes to the migrating unit relative and other relatives variables: the numbers of both of these types of relatives living with the Principal Applicant would be expected to decrease with duration in 
Australia. $^{27}$

There are several pronounced trends in the family structure effects. First, the negative effect of having a migrating unit spouse intensifies. Second, the negative effect of living with a spouse who was not part of the migrating unit lessens. The relative magnitudes of the effects of migrating unit and other spouses in the wave three data are consistent with expectations: migrating unit spouses will have a greater permanent negative impact on the language skills of the Principal Applicant partners than would other spouses. The longer the immigrant has resided in Australia, the more likely it is that the marriages that take place will be to individuals proficient in English.

Models of the determinants of English reading and writing skills comparable to those reported for English speaking skills were also estimated. The general patterns are similar to those discussed above for speaking skills, and so only brief comments are offered. Relevant estimates are presented in Table 7. Only those obtained for the encompassing model (equation (3)) are considered.

The two key features of the effects of the personal characteristics included in the model developed in Section II on English-speaking skills carry over to the study of English reading and writing skills. Thus, the effect of age at migration on each of the English language skills intensifies with length of residence in Australia, whereas the effect of educational attainment on these skills is quite stable across the analyses at the different lengths of residence in Australia. As argued above, this provides some insights into the mechanisms through which these characteristics influence English skills. The intensification of the age at migration effects with duration of residence indicates that this impact is associated with the greater efficiency of the young in second language acquisition, which cumulates through time. The stability of the

${ }^{27}$ The mean values for the family structure variables across the three waves of the data are as follows.

\begin{tabular}{lccc}
\hline Variable & Wave One & Wave Two & Wave Three \\
\hline Migrating Unit Spouse & 0.345 & 0.351 & 0.360 \\
Other Spouse & 0.379 & 0.397 & 0.417 \\
KIDS & 0.396 & 0.484 & 0.591 \\
Migrating Unit Relative & 0.023 & 0.020 & 0.019 \\
Other Relative & 0.334 & 0.231 & 0.193 \\
\hline
\end{tabular}


estimated effect of educational attainment suggests that these capture pre-immigration influences such as the exposure to English gained through tertiary-level education.

The main birthplace effect established in the analysis of English reading and writing skills is for residence in a former British colony. The impact of this preimmigration exposure factor decreases in size with duration of residence in Australia. This would be expected where post-immigration exposure takes on a greater role. The same interpretation can be attached to the decrease in the size of the favourable effect on English reading and writing skills of having visited Australia prior to migration.

In comparison, the effect of cross-country/culture contact in the former home country intensifies with duration of residence in Australia. It was argued earlier that this variable may capture the preparedness of the immigrant to learn English, in which case the impact would be expected to cumulate through time in the same way as that associated with the age at migration variable.

The estimated impact of residence in an area with a high concentration of compatriots from the immigrant's country of origin is irregular in the analyses of English reading and writing skills. Moreover, where the estimated effects are statistically significant, the impact of the birthplace concentration variable is much weaker in the study of English reading and writing skills than it is in the study of English-speaking skills. As speech has a public good element the presence of others who speak an immigrant's mother tongue would be expected to facilitate conversations in the mother tongue and hence slow the development of Englishspeaking skills. Reading and writing do not necessarily have this public good element, and so it would be expected that the birthplace concentration variable will have a lesser impact in the analysis of these skills than in the case of the study of the determinants of English speaking proficiency. Chiswick and Miller (1998b) report similar findings in a study of English-speaking and reading skills among legalized aliens in the US, where it is argued that this result emerges because speaking, but not reading, requires the active participation of a second person. Similar arguments apply to the links between the various family structure variables included in the estimating equations and English reading and writing skills in comparison to the effects of these variables on English- speaking skills. 


\section{BIVARIATE PROBIT ANALYSES}

The analyses presented above have traced the development of English skills through an examination of the links between these skills and observed characteristics at different lengths of residence in Australia. It is also possible to use the information collected in the three waves of the survey to provide information on the role unmeasured characteristics might play in the development of these skills. This can be

achieved by estimating bivariate probit models, where the equations that are part of the bivariate probit model are for English skills at different waves of interviews. Valuable information on the role of unobserved characteristics can be obtained by examining the correlation between the disturbances in the estimating equations for individuals who were interviewed in different waves, and using this information when inferring the impact of observed characteristics on English skills.

The joint probability of an individual being proficient in two waves (a and b) of the survey can be obtained by estimating the bivariate probit model represented by:

$$
\operatorname{Pr}\left(L A N G_{i}^{a}=1, L A N G_{i}^{b}=1\right)=F\left(\beta^{a} X_{i}^{a}, \beta^{b} X_{i}^{b}, \rho\right)
$$

where $\mathrm{F}$ is the cumulative standard bivariate normal and $\rho$ denotes the correlation between the disturbances in the estimating equations for individuals who were interviewed in different waves. The coefficients in the models of language skills for different waves are allowed to differ in this model.

The interpretation of $\rho$ is that it captures the correlation between the effects of unobservables in the models of language skills of the individuals in two different waves of interviews. If the unobservable effects are purely random across time, then there will be zero correlation between the disturbance terms in the models of English skills estimated for specific waves of the survey. A positive correlation between the error terms between two waves of interviews would be expected if the same unobservables are relevant in the two time periods. If there is a regression to the mean, the correlation should be lower the more distant the waves of the survey used in the analysis. That is, the correlation between waves 1 and 3 should be lower than the correlation between the unobserved effects for either waves 1 and 2 or waves 2 and 3 . Another possibility of a positive correlation is that individuals who initially had a higher than expected proficiency in English continue to have a higher than expected 
proficiency in English (with a steeper improvement), while those who initially had a lower than expected proficiency in English not only do not improve but actually fall further behind. In such a situation, the correlations are all positive, though the wave 1 to wave 3 correlation between the effects of unobservables should be larger than that in either the wave 1 and wave 2 or wave 2 and wave 3 analyses.

The bivariate probit models are estimated on a sample restricted to individuals who had valid data in each of the three waves of the survey. There are 2,304 respondents that meet this requirement.

The estimates for the probit models of English skills at the various waves of the LSIA that enter into the bivariate probit models examined here are very similar to the single equation models reported above. Thus, these estimates will not be reported here: Appendix C, however, contains a representative set of estimates. Rather attention will focus on the correlation coefficients between the disturbance terms in the various models estimated. There are presented in Table 8.

There are two key features of Table 8. First, all the correlation coefficients are very large. They range from a high of 0.85 for speaking in waves 1 and 2 , to a low of 0.62 for reading for waves 1 and 3 . The correlations across waves are not systematically higher for one language skills than for another.

There is no comparison literature, and so size needs to be assessed by reference to related models. Chiswick, Lee and Miller (2002) examine the correlation between the disturbance terms in models of English skills estimated for spouses in migrating units within the LSIA data set that is utilized in the current study. The largest correlation coefficient in this related study is 0.422 . It is to be expected that the positive correlation in unmeasured effects across time for an individual would be larger than the positive correlation across spouses at a point in time. Simulations presented in Chiswick, Lee and Miller (2002) show that correlation coefficients of this magnitude have the potential to have a pronounced impact on the predictions of English proficiency obtained from the model of English skills. This comparison suggests that the correlation coefficients listed in Table 8 are indeed quite large.

Second, the correlation coefficients obtained for when the bivariate probit model is based on contiguous waves of the survey are larger than the correlation coefficient obtained when the bivariate probit model is based on data obtained from waves one and three of the LSIA. For example, consider the estimates obtained for speaking skills. When the analysis is for waves one and two the correlation coefficient 
is 0.854 ; for waves two and three the correlation coefficient is 0.790 , while for waves one and three the correlation coefficient is 0.728 . These data, and the other data listed in the Table 8, are consistent with the "regression to the mean" phenomenon outlined above. That is, those who for unmeasured reasons have much greater (or much poorer) English language proficiency in wage one also have greater (poorer) proficiency in the subsequent waves, but on average their divergence from the mean proficiency decreases with subsequent waves.

\section{SUMMARY AND CONCLUSION}

The primary focus of this paper is on the determinants of the improvement in English language skills with time in Australia among immigrants from non-English speaking countries.

A model of the determinants of English language skills is presented based on economic incentives for investing in this skill, exposure to English in the origin and destination, and efficiency in second language acquisition. Hypotheses are developed for measurable variable that reflect these more fundamental concepts. The hypotheses are found to be consistent with the data.

The model is estimated using the Longitudinal Survey of Immigrants to Australia (LSIA), which is a sample of principal applicant immigrants over a two year period (1993-95) who received their visa prior to immigrating. The respondents were interviewed in three waves: wave one at 5 to 6 months after immigration, wave two one year later (about 18 months after immigration) and wave three two years later (about 31/2 years after immigration). Three dimensions of English language skills are considered: speaking, reading and writing. Probit analysis is used within waves and bivariate probit is used for analyses across survey waves

About half of all the immigrants sampled report that they can speak and write English at six months after arrival, but a larger proportion (two-thirds) can read English. The mean rate of English speaking and writing proficiency increases by about 10 percentage points over the next year, while reading proficiency increases by about 5 percentage points. Over the next two years proficiency rates increase (from wave two to wave three), but by a lesser amount, about 5 percentage points for speaking and 3 to 4 percentage points for reading and writing skills. 
In the econometric analysis of the model, mutually consistent finding are found across waves, type of language skill and gender. In general, English language skills are greater for those with more schooling, who immigrated at a younger age, who are male and who immigrated as economic migrants (Independent and Business Skills Migrants), as distinct from family-based migrants (Concessional and Preferential), and are poorest among refugees. Proficiency is also greater among those who came from a former British colony, visited Australia prior to immigrating, expect to stay permanently, with an origin language more "distant" from English and while in Australia have fewer ties to immigrants from their origin.

The impact on English proficiency of some variables decreases as the analysis goes to later waves (e.g., visa category and some other pre-immigration characteristics), remains the same for other variables (e.g., education) and increases in intensity for still others (e.g., age at migration). Migrating with a spouse is associated with lower proficiency, and this negative effect intensifies at later waves. The negative effect of living among others who speak the respondent's origin language is greater for speaking skills than for reading and writing skills.

Using bivariate probit analysis it is possible to estimate the correlation of the unexplained component (error terms) across waves. These positive correlations are quite large, but for all three types of language skills show the same pattern. The correlation for adjacent waves are similar but higher than the correlation between waves one and three. This suggests a "regression to the mean". Those with very high (low) language skills at wave one for unmeasured reasons also have high (lower) language skills in waves two and three, but their gap from the mean proficiency decreases the longer they are in Australia.

The analysis has documented the improvement in destination language skills among immigrants the longer the duration of residence. The model of language proficiency is found to be robust across survey waves, type of language proficiency (speaking, reading and writing) and gender. Moreover, the analysis documents which determinants increase in intensity and which decrease in intensity as duration of residence increases. 
TABLE 1: English Speaking, Reading and Writing Skills by Birthplace Region, 15-64 Year Old Males and Females from Non-English Speaking Countries ${ }^{\text {(a) }}$

Panel A: All Respondents in Wave One

\begin{tabular}{|c|c|c|c|}
\hline \multirow[b]{2}{*}{ Birthplace } & \multicolumn{3}{|c|}{$\%$ Proficient in Wave One } \\
\hline & Speaking & Reading & Writing \\
\hline Southern Europe & 29.12 & 37.29 & 26.29 \\
\hline Western Europe & 95.25 & 91.14 & 85.27 \\
\hline Northern Europe & 96.88 & 88.58 & 83.71 \\
\hline Eastern Europe & 32.56 & 50.25 & 34.52 \\
\hline The USSR \& the Baltic States & 38.93 & 55.40 & 41.50 \\
\hline The Middle East & 30.02 & 47.81 & 38.14 \\
\hline North Africa & 56.54 & 76.55 & 66.39 \\
\hline South East Asia & 47.77 & 54.69 & 50.53 \\
\hline North East Asia & 55.09 & 70.41 & 60.40 \\
\hline Southern Asia & 80.57 & 90.23 & 87.93 \\
\hline South and Central America & 40.53 & 60.58 & 45.98 \\
\hline Mean Proficiency & 50.87 & 61.60 & 54.11 \\
\hline \multicolumn{4}{|c|}{ Panel B: Wave One Respondents who were also surveyed in Wave Two } \\
\hline \multirow[b]{2}{*}{ Birthplace } & \multicolumn{3}{|c|}{$\%$ Proficient in Wave One } \\
\hline & Speaking & Reading & Writing \\
\hline Southern Europe & 28.88 & 37.49 & 26.26 \\
\hline Western Europe & 95.57 & 92.77 & 87.02 \\
\hline Northern Europe & 97.16 & 87.64 & 82.07 \\
\hline Eastern Europe & 32.96 & 51.19 & 34.33 \\
\hline The USSR \& the Baltic States & 40.48 & 57.06 & 42.58 \\
\hline The Middle East & 29.78 & 47.13 & 38.37 \\
\hline North Africa & 55.60 & 75.63 & 67.30 \\
\hline South East Asia & 48.63 & 55.51 & 50.41 \\
\hline North East Asia & 57.39 & 72.49 & 63.03 \\
\hline Southern Asia & 80.49 & 90.39 & 87.76 \\
\hline South and Central America & 39.13 & 59.99 & 46.06 \\
\hline Mean Proficiency & 51.41 & 62.18 & 54.52 \\
\hline \multicolumn{4}{|c|}{ Panel C: Wave One Respondents who were also surveyed in Wave Three } \\
\hline \multirow[b]{2}{*}{ Birthplace } & \multicolumn{3}{|c|}{$\%$ Proficient in Wave One } \\
\hline & Speaking & Reading & Writing \\
\hline Southern Europe & 29.73 & 38.39 & 27.10 \\
\hline Western Europe & 95.05 & 91.35 & 85.09 \\
\hline Northern Europe & 96.16 & 83.27 & 76.74 \\
\hline Eastern Europe & 34.03 & 52.46 & 35.31 \\
\hline The USSR \& the Baltic States & 38.57 & 56.31 & 40.83 \\
\hline The Middle East & 30.08 & 44.50 & 35.68 \\
\hline North Africa & 57.80 & 74.18 & 68.13 \\
\hline South East Asia & 50.14 & 57.43 & 52.18 \\
\hline North East Asia & 55.89 & 71.86 & 61.22 \\
\hline Southern Asia & 79.47 & 90.12 & 87.91 \\
\hline South and Central America & 38.09 & 60.54 & 44.02 \\
\hline Mean Proficiency & 51.52 & 62.10 & 54.28 \\
\hline
\end{tabular}

(a) The total number of cases is 3980 for Panel A, 3420 for Panel B and 2763 for Panel C. These data are weighted using sample weights to reflect populations of 53476, 45710 and 36646, respectively.

Source: Longitudinal Survey of Immigrants to Australia (Wave One) 
TABLE 2: English Speaking, Reading and Writing Skills by Birthplace Region, 15-64 Year Old Males and Females from Non-English Speaking Countries ${ }^{(a)}$

Panel A: All Respondents in Wave Two

\begin{tabular}{lccc}
\hline \multirow{2}{*}{ Birthplace } & \multicolumn{3}{c}{ \% Proficient in Wave Two } \\
\cline { 2 - 4 } Southern Europe & Speaking & Reading & Writing \\
Western Europe & 45.82 & 59.62 & 43.37 \\
Northern Europe & 98.50 & 94.94 & 90.50 \\
Eastern Europe & 97.13 & 97.13 & 82.11 \\
The USSR \& the Baltic States & 58.84 & 69.99 & 58.35 \\
The Middle East & 60.97 & 72.49 & 55.74 \\
North Africa & 50.56 & 60.27 & 45.80 \\
South East Asia & 69.64 & 77.87 & 68.97 \\
North East Asia & 50.25 & 59.00 & 53.18 \\
Southern Asia & 63.36 & 74.12 & 62.54 \\
South and Central America & 86.18 & 93.25 & 92.41 \\
Mean Proficiency & 55.92 & 69.07 & 57.23 \\
& 60.19 & 69.45 & 59.46 \\
\hline
\end{tabular}

Panel B: Wave Two Respondents who were also surveyed in Wave Three

\begin{tabular}{lccc}
\hline & \multicolumn{3}{c}{ \% Proficient in Wave Two } \\
\cline { 2 - 4 } Birthplace & Speaking & Reading & Writing \\
\hline Southern Europe & 48.45 & 62.40 & 47.78 \\
Western Europe & 98.09 & 94.17 & 90.51 \\
Northern Europe & 96.10 & 96.10 & 76.89 \\
Eastern Europe & 61.46 & 73.93 & 58.48 \\
The USSR \& the Baltic States & 59.06 & 72.00 & 55.03 \\
The Middle East & 50.65 & 60.01 & 44.33 \\
North Africa & 70.64 & 76.53 & 66.92 \\
South East Asia & 50.94 & 61.04 & 53.02 \\
North East Asia & 61.67 & 71.41 & 60.68 \\
Southern Asia & 85.49 & 92.24 & 89.37 \\
South and Central America & 54.02 & 68.49 & 57.82 \\
Mean Proficiency & 60.22 & 69.72 & 59.68
\end{tabular}

\footnotetext{
${ }^{(a)}$ The total number of cases is 3420 for Panel A and 2763 for Panel B. These data are weighted using
} sample weights to reflect populations of 50285 and 40209, respectively.

Source: Longitudinal Survey of Immigrants to Australia (Wave Two) 
TABLE 3: English Speaking, Reading and Writing Skills by Birthplace Region, 15-64 Year Old Males and Females from Non-English Speaking Countries ${ }^{(a)}$

\begin{tabular}{lccc}
\hline \multirow{2}{*}{ Birthplace } & \multicolumn{3}{c}{ \% Proficient in Wave Three } \\
\cline { 2 - 4 } Southern Europe & Speaking & Reading & Writing \\
Western Europe & 61.13 & 67.13 & 49.37 \\
Northern Europe & 99.11 & 97.38 & 91.07 \\
Eastern Europe & 97.90 & 100.00 & 91.89 \\
The USSR \& the Baltic States & 72.40 & 80.82 & 63.93 \\
The Middle East & 66.08 & 79.24 & 57.19 \\
North Africa & 64.24 & 66.40 & 51.08 \\
South East Asia & 75.24 & 85.12 & 74.46 \\
North East Asia & 54.74 & 62.07 & 54.96 \\
Southern Asia & 66.30 & 72.53 & 68.02 \\
South and Central America & 87.46 & 95.85 & 90.02 \\
Mean Proficiency & 68.44 & 76.99 & 63.80 \\
\end{tabular}

${ }^{(a)}$ The total number of cases is 2868 . These data are weighted using sample weights to reflect a population of 47651 .

$\underline{\text { Source: }}$ Longitudinal Survey of Immigrants to Australia (Wave Three) 
TABLE 4: English Speaking Skills by Assistance of Interpreter Since Arrival in Australia, 15-64 Year Old Males and Females from Non-English Speaking Countries

\begin{tabular}{lccc}
\hline $\begin{array}{l}\text { Need of an } \\
\text { Interpreter }\end{array}$ & \multicolumn{2}{c}{ English Speaking Skill Level ${ }^{(\mathrm{b})}$} & Total \\
\cline { 2 - 3 } Yes & 76.52 & Not at all & 76.63 \\
No & 23.48 & 76.90 & 23.37 \\
Total $^{(\mathrm{a})}$ & 100.00 & 23.10 & 100.00 \\
$\%$ of Population $^{2}$ & 70.83 & 100.00 & 100.00 \\
\hline
\end{tabular}

\footnotetext{
${ }^{(a)}$ The total number of cases is 1870 . These data are weighted using sample weights to reflect a population of 26275 .

(b) Question "Have you needed to use an interpreter since you immigrated to Australia" asked only of these two speaking categories.

Source: Longitudinal Survey of Immigrants to Australia (Wave One)
} 
TABLE 5: Probit Models of English Speaking Skills, 15-64 Year Old Males and Females from Non-English Speaking Countries

\begin{tabular}{|c|c|c|c|}
\hline Variable & (1) & $(2)$ & (3) \\
\hline Constant & $\begin{array}{l}-1.660 \\
(7.34)\end{array}$ & $\begin{array}{l}-0.256 \\
(0.68)\end{array}$ & $\begin{array}{l}-3.493 \\
(5.35)\end{array}$ \\
\hline $\begin{array}{l}\text { Visa Category } \\
\text { Humanitarian } \\
\text { (Refugee) }\end{array}$ & $\begin{array}{l}-1.450 \\
(11.68)\end{array}$ & $\begin{array}{l}-0.796 \\
(6.62)\end{array}$ & $\begin{array}{c}-0.932 \\
(7.06)\end{array}$ \\
\hline $\begin{array}{l}\text { Preferential } \\
\text { Family }\end{array}$ & $\begin{array}{l}-0.592 \\
(4.55)\end{array}$ & $\begin{array}{l}-0.357 \\
(2.57)\end{array}$ & $\begin{array}{r}-0.479 \\
(3.30)\end{array}$ \\
\hline $\begin{array}{l}\text { Concessional } \\
\text { Family }\end{array}$ & $\begin{array}{l}-0.571 \\
(4.46)\end{array}$ & $\begin{array}{l}-0.465 \\
(3.52)\end{array}$ & $\begin{array}{r}-0.584 \\
(4.23)\end{array}$ \\
\hline $\begin{array}{l}\text { Business } \\
\text { Skills/ENS }\end{array}$ & $\begin{array}{l}-0.502 \\
(2.57)\end{array}$ & $\begin{array}{l}-0.355 \\
(1.81)\end{array}$ & $\begin{array}{r}-0.355 \\
(1.71)\end{array}$ \\
\hline Age at migration & $\begin{array}{l}-0.007 \\
(2.30)\end{array}$ & $\begin{array}{r}-0.015 \\
(5.07)\end{array}$ & $\begin{array}{r}-0.013 \\
(4.12)\end{array}$ \\
\hline Education & $\begin{array}{c}0.213 \\
(21.79)\end{array}$ & $\begin{array}{c}0.182 \\
(17.87)\end{array}$ & $\begin{array}{c}0.202 \\
(18.36)\end{array}$ \\
\hline Female & $\begin{array}{l}-0.085 \\
(1.43)\end{array}$ & $\begin{array}{r}-0.164 \\
(2.68)\end{array}$ & $\begin{array}{r}-0.128 \\
(1.98)\end{array}$ \\
\hline $\begin{array}{l}\text { Birthplace } \\
\text { Western Europe }\end{array}$ & $\begin{array}{l}1.696 \\
(7.98)\end{array}$ & (a) & $\begin{array}{l}1.577 \\
(7.28)\end{array}$ \\
\hline Northern Europe & $\begin{array}{l}2.032 \\
(4.96)\end{array}$ & (a) & $\begin{array}{l}1.971 \\
(4.59)\end{array}$ \\
\hline Eastern Europe & $\begin{array}{l}-0.621 \\
(3.65)\end{array}$ & (a) & $\begin{array}{l}-0.482 \\
(2.79)\end{array}$ \\
\hline $\begin{array}{l}\text { The USSR \& the } \\
\text { Baltic States }\end{array}$ & $\begin{array}{l}-0.610 \\
(3.75)\end{array}$ & (a) & $\begin{array}{l}-0.475 \\
(2.87)\end{array}$ \\
\hline The Middle East & $\begin{array}{l}-0.013 \\
(0.12)\end{array}$ & (a) & $\begin{array}{l}0.148 \\
(0.95)\end{array}$ \\
\hline North Africa & $\begin{array}{l}-0.072 \\
(0.39)\end{array}$ & (a) & $\begin{array}{l}0.424 \\
(1.90)\end{array}$ \\
\hline South East Asia & $\begin{array}{l}0.584 \\
(5.99)\end{array}$ & (a) & $\begin{array}{l}0.736 \\
(2.31)\end{array}$ \\
\hline North East Asia & $\begin{array}{l}-0.110 \\
(1.00)\end{array}$ & (a) & $\begin{array}{r}-0.219 \\
(0.71)\end{array}$ \\
\hline
\end{tabular}




\begin{tabular}{|c|c|c|c|}
\hline Southern Asia & $\begin{array}{l}0.852 \\
(6.61)\end{array}$ & (a) & $\begin{array}{r}-0.239 \\
(0.86)\end{array}$ \\
\hline $\begin{array}{l}\text { South and Central } \\
\text { America }\end{array}$ & $\begin{array}{l}-0.328 \\
(1.84)\end{array}$ & (a) & $\begin{array}{l}-0.247 \\
(1.14)\end{array}$ \\
\hline $\begin{array}{l}\text { Former British } \\
\text { colony }\end{array}$ & (a) & $\begin{array}{c}1.369 \\
(16.88)\end{array}$ & $\begin{array}{c}1.558 \\
(14.82)\end{array}$ \\
\hline $\begin{array}{l}\text { Cross country/culture } \\
\text { contact in former } \\
\text { home country }\end{array}$ & (a) & $\begin{array}{l}0.187 \\
(3.24)\end{array}$ & $\begin{array}{l}0.210 \\
(3.49)\end{array}$ \\
\hline $\begin{array}{l}\text { Previously visited } \\
\text { Australia }\end{array}$ & (a) & $\begin{array}{l}0.608 \\
(8.98)\end{array}$ & $\begin{array}{l}0.655 \\
(8.53)\end{array}$ \\
\hline $\begin{array}{l}\text { Main reason for choosing State settled } \\
\text { was Family/Friends }\end{array}$ & $\begin{array}{l}-0.181 \\
(2.29)\end{array}$ & $\begin{array}{l}-0.176 \\
(2.12)\end{array}$ & $\begin{array}{r}-0.140 \\
(1.62)\end{array}$ \\
\hline Contact with ethnic agencies & (a) & $\begin{array}{l}-0.066 \\
(1.03)\end{array}$ & $\begin{array}{r}-0.047 \\
(0.70)\end{array}$ \\
\hline Expect to leave Australia & (a) & $\begin{array}{l}-0.375 \\
(2.89)\end{array}$ & $\begin{array}{l}-0.462 \\
(3.30)\end{array}$ \\
\hline Birthplace concentration & (a) & $\begin{array}{l}-0.008 \\
(1.64)\end{array}$ & $\begin{array}{l}-0.024 \\
(2.99)\end{array}$ \\
\hline Distance/1000 & (a) & $\begin{array}{c}-0.086 \\
(1.31)\end{array}$ & $\begin{array}{l}0.333 \\
(3.57)\end{array}$ \\
\hline Distance $^{2} / 1 \mathrm{~m}$. & (a) & $\begin{array}{l}0.004 \\
(1.42)\end{array}$ & $\begin{array}{l}-0.013 \\
(2.89)\end{array}$ \\
\hline Linguistic distance & (a) & $\begin{array}{l}-1.751 \\
(6.51)\end{array}$ & $\begin{array}{l}-0.913 \\
(2.24)\end{array}$ \\
\hline $\begin{array}{l}\text { Family Structure } \\
\text { MUS }^{(\mathrm{c})}\end{array}$ & $\begin{array}{l}-0.221 \\
(2.35)\end{array}$ & $\begin{array}{l}-0.242 \\
(2.49)\end{array}$ & $\begin{array}{r}-0.236 \\
(2.37)\end{array}$ \\
\hline $\mathrm{OS}^{(\mathrm{d})}$ & $\begin{array}{l}-0.406 \\
(4.23)\end{array}$ & $\begin{array}{l}-0.285 \\
(2.78)\end{array}$ & $\begin{array}{c}-0.393 \\
(3.71)\end{array}$ \\
\hline $\operatorname{KIDS}^{(\mathrm{e})}$ & $\begin{array}{l}-0.129 \\
(1.95)\end{array}$ & $\begin{array}{l}-0.165 \\
(2.41)\end{array}$ & $\begin{array}{r}-0.116 \\
(1.61)\end{array}$ \\
\hline $\operatorname{MUR}^{(\mathrm{f})}$ & $\begin{array}{l}0.119 \\
(0.79)\end{array}$ & $\begin{array}{l}-0.094 \\
(0.61)\end{array}$ & $\begin{array}{c}-0.036 \\
(0.23)\end{array}$ \\
\hline $\mathrm{OR}^{(\mathrm{g})}$ & $\begin{array}{c}-0.307 \\
(5.04)\end{array}$ & $\begin{array}{l}-0.288 \\
(4.49)\end{array}$ & $\begin{array}{c}-0.252 \\
(3.77)\end{array}$ \\
\hline$\chi^{2}$ & 1695.53 & 1961.14 & 2173.26 \\
\hline
\end{tabular}


Note: Numbers in parentheses are 't' statistics.

(a) Variable not entered.

(b) ENS denotes Employer Nomination Scheme.

${ }^{\text {(c) }}$ Whether a spouse who was part of the migrating unit is present in the household.

(d) Whether a spouse who was not part of the migrating unit is present in the household.

${ }^{\text {(e) }}$ Whether children in the household.

(f) Whether other relatives who gained approval to migrate to Australia as part of the Principal Applicant's migration application are present in the household.

${ }^{(g)}$ Whether other relatives are present in the household.

(h) The total number of cases is 3418 . These data are weighted using sample weights to reflect a population of 48463 .

The benchmark group defined by the omitted categorical variables is male immigrants from Southern Europe who entered Australia under Independent visas, did not report cross country/culture in the former home country, did not visit Australia prior to migration, chose their initial State settled for reasons other than Family/Friends, did not have post-immigration contact with ethnic agencies and do not expect to leave Australia.

Source: Longitudinal Survey of Immigrants to Australia (Wave One) 
TABLE 6: Probit Models of English Speaking Skills, 15-64 Year Old Males and Females from Non-English Speaking Countries, Longitudinal Survey of Immigrants to Australia, Waves Two and Three

\begin{tabular}{|c|c|c|c|c|c|c|}
\hline \multirow[t]{2}{*}{ Variable } & \multicolumn{3}{|c|}{ Wave Two } & \multicolumn{3}{|c|}{ Wave Three } \\
\hline & (1) & (2) & (3) & (1) & (2) & (3) \\
\hline Constant & $\begin{array}{l}-0.748 \\
(3.16)\end{array}$ & $\begin{array}{l}-0.094 \\
(0.22)\end{array}$ & $\begin{array}{l}-0.359 \\
(0.51)\end{array}$ & $\begin{array}{l}-0.079 \\
(0.29)\end{array}$ & $\begin{array}{l}1.179 \\
(2.49)\end{array}$ & $\begin{array}{l}0.294 \\
(0.39)\end{array}$ \\
\hline $\begin{array}{l}\text { Visa Category } \\
\text { Humanitarian } \\
\text { (Refugee) }\end{array}$ & $\begin{array}{l}-0.972 \\
(7.07)\end{array}$ & $\begin{array}{l}-0.407 \\
(3.03)\end{array}$ & $\begin{array}{l}-0.431 \\
(2.95)\end{array}$ & $\begin{array}{l}-0.844 \\
(5.39)\end{array}$ & $\begin{array}{c}-0.179 \\
(1.16)\end{array}$ & $\begin{array}{l}-0.238 \\
(1.43)\end{array}$ \\
\hline $\begin{array}{l}\text { Preferential } \\
\text { Family }\end{array}$ & $\begin{array}{l}-0.575 \\
(4.04)\end{array}$ & $\begin{array}{l}-0.394 \\
(2.59)\end{array}$ & $\begin{array}{l}-0.435 \\
(2.79)\end{array}$ & $\begin{array}{l}-0.622 \\
(4.02)\end{array}$ & $\begin{array}{l}-0.265 \\
(1.63)\end{array}$ & $\begin{array}{l}-0.322 \\
(1.92)\end{array}$ \\
\hline $\begin{array}{l}\text { Concessional } \\
\text { Family }\end{array}$ & $\begin{array}{l}-0.459 \\
(3.14)\end{array}$ & $\begin{array}{l}-0.361 \\
(2.39)\end{array}$ & $\begin{array}{l}-0.389 \\
(2.51)\end{array}$ & $\begin{array}{l}-0.280 \\
(1.66)\end{array}$ & $\begin{array}{c}-0.159 \\
(0.91)\end{array}$ & $\begin{array}{l}-0.207 \\
(1.16)\end{array}$ \\
\hline $\begin{array}{l}\text { Business } \\
\text { Skills/ENS }\end{array}$ & $\begin{array}{l}-0.290 \\
(1.24)\end{array}$ & $\begin{array}{l}-0.296 \\
(1.23)\end{array}$ & $\begin{array}{l}-0.278 \\
(1.13)\end{array}$ & $\begin{array}{l}-0.395 \\
(1.54)\end{array}$ & $\begin{array}{l}-0.409 \\
(1.56)\end{array}$ & $\begin{array}{l}-0.445 \\
(1.63)\end{array}$ \\
\hline Age at migration & $\begin{array}{r}-0.020 \\
(6.37)\end{array}$ & $\begin{array}{l}-0.030 \\
(9.37)\end{array}$ & $\begin{array}{l}-0.029 \\
(8.48)\end{array}$ & $\begin{array}{l}-0.033 \\
(9.20)\end{array}$ & $\begin{array}{l}-0.045 \\
(11.89)\end{array}$ & $\begin{array}{l}-0.043 \\
(10.91)\end{array}$ \\
\hline Education & $\begin{array}{c}0.202 \\
(20.44)\end{array}$ & $\begin{array}{c}0.176 \\
(17.13)\end{array}$ & $\begin{array}{c}0.184 \\
(16.97)\end{array}$ & $\begin{array}{c}0.199 \\
(18.32)\end{array}$ & $\begin{array}{c}0.164 \\
(14.53)\end{array}$ & $\begin{array}{c}0.175 \\
(14.64)\end{array}$ \\
\hline Female & $\begin{array}{l}-0.039 \\
(0.61)\end{array}$ & $\begin{array}{l}-0.098 \\
(1.49)\end{array}$ & $\begin{array}{l}-0.066 \\
(0.98)\end{array}$ & $\begin{array}{l}-0.181 \\
(2.52)\end{array}$ & $\begin{array}{l}-0.305 \\
(4.09)\end{array}$ & $\begin{array}{l}-0.279 \\
(3.63)\end{array}$ \\
\hline $\begin{array}{l}\text { Birthplace } \\
\text { Western Europe }\end{array}$ & $\begin{array}{l}1.923 \\
(5.57)\end{array}$ & (a) & $\begin{array}{l}1.766 \\
(5.11)\end{array}$ & $\begin{array}{l}1.908 \\
(3.68)\end{array}$ & (a) & $\begin{array}{l}1.897 \\
(3.55)\end{array}$ \\
\hline Northern Europe & $\begin{array}{l}1.601 \\
(3.39)\end{array}$ & (a) & $\begin{array}{l}1.513 \\
(3.01)\end{array}$ & $\begin{array}{l}1.377 \\
(2.17)\end{array}$ & (a) & $\begin{array}{l}1.368 \\
(2.10)\end{array}$ \\
\hline Eastern Europe & $\begin{array}{l}-0.120 \\
(0.69)\end{array}$ & (a) & $\begin{array}{l}0.065 \\
(0.37)\end{array}$ & $\begin{array}{l}-0.090 \\
(0.44)\end{array}$ & (a) & $\begin{array}{l}0.165 \\
(0.79)\end{array}$ \\
\hline $\begin{array}{l}\text { The USSR \& the } \\
\text { Baltic States }\end{array}$ & $\begin{array}{l}-0.203 \\
(1.26)\end{array}$ & (a) & $\begin{array}{l}0.016 \\
(0.09)\end{array}$ & $\begin{array}{l}-0.397 \\
(2.13)\end{array}$ & (a) & $\begin{array}{l}-0.146 \\
(0.76)\end{array}$ \\
\hline The Middle East & $\begin{array}{l}0.163 \\
(1.51)\end{array}$ & (a) & $\begin{array}{l}0.204 \\
(1.25)\end{array}$ & $\begin{array}{l}0.051 \\
(0.40)\end{array}$ & (a) & $\begin{array}{l}0.249 \\
(1.31)\end{array}$ \\
\hline North Africa & $\begin{array}{l}0.003 \\
(0.02)\end{array}$ & (a) & $\begin{array}{l}0.239 \\
(0.98)\end{array}$ & $\begin{array}{l}-0.210 \\
(0.94)\end{array}$ & (a) & $\begin{array}{l}0.173 \\
(0.63)\end{array}$ \\
\hline South East Asia & $\begin{array}{l}0.173 \\
(1.74)\end{array}$ & (a) & $\begin{array}{l}-0.253 \\
(0.71)\end{array}$ & $\begin{array}{l}-0.222 \\
(1.89)\end{array}$ & (a) & $\begin{array}{c}-0.0 .33 \\
(0.08)\end{array}$ \\
\hline
\end{tabular}




\begin{tabular}{|c|c|c|c|c|c|c|}
\hline North East Asia & $\begin{array}{l}-0.071 \\
(0.61)\end{array}$ & (a) & $\begin{array}{l}-0.656 \\
(1.92)\end{array}$ & $\begin{array}{r}-0.500 \\
(3.60)\end{array}$ & (a) & $\begin{array}{l}-0.472 \\
(1.20)\end{array}$ \\
\hline Southern Asia & $\begin{array}{l}0.861 \\
(5.99)\end{array}$ & (a) & $\begin{array}{l}-0.207 \\
(0.66)\end{array}$ & $\begin{array}{l}0.367 \\
(2.34)\end{array}$ & (a) & $\begin{array}{l}-0.426 \\
(1.16)\end{array}$ \\
\hline $\begin{array}{l}\text { South and Central } \\
\text { America }\end{array}$ & $\begin{array}{l}-0.188 \\
(0.99)\end{array}$ & (a) & $\begin{array}{r}-0.030 \\
(0.13)\end{array}$ & $\begin{array}{r}-0.286 \\
(1.27)\end{array}$ & (a) & $\begin{array}{l}0.021 \\
(0.08)\end{array}$ \\
\hline $\begin{array}{l}\text { Former British } \\
\text { colony }\end{array}$ & (a) & $\begin{array}{c}1.334 \\
(14.57)\end{array}$ & $\begin{array}{c}1.288 \\
(11.54)\end{array}$ & (a) & $\begin{array}{c}1.268 \\
(12.40)\end{array}$ & $\begin{array}{c}1.385 \\
(10.36)\end{array}$ \\
\hline $\begin{array}{l}\text { Cross } \\
\text { country/culture } \\
\text { contact in former } \\
\text { home country }\end{array}$ & (a) & $\begin{array}{l}0.133 \\
(2.16)\end{array}$ & $\begin{array}{l}0.158 \\
(2.49)\end{array}$ & (a) & $\begin{array}{l}0.230 \\
(3.31)\end{array}$ & $\begin{array}{l}0.248 \\
(3.49)\end{array}$ \\
\hline $\begin{array}{l}\text { Previously visited } \\
\text { Australia }\end{array}$ & (a) & $\begin{array}{l}0.660 \\
(8.30)\end{array}$ & $\begin{array}{l}0.656 \\
(7.63)\end{array}$ & (a) & $\begin{array}{l}0.416 \\
(4.60)\end{array}$ & $\begin{array}{l}0.425 \\
(4.34)\end{array}$ \\
\hline $\begin{array}{l}\text { Main reason for } \\
\text { choosing State } \\
\text { settled was } \\
\text { Family/Friends }\end{array}$ & $\begin{array}{l}-0.224 \\
(2.58)\end{array}$ & $\begin{array}{l}-0.259 \\
(2.87)\end{array}$ & $\begin{array}{l}-0.253 \\
(2.73)\end{array}$ & $\begin{array}{l}-0.287 \\
(2.83)\end{array}$ & $\begin{array}{r}-0.292 \\
(2.74)\end{array}$ & $\begin{array}{l}-0.301 \\
(2.75)\end{array}$ \\
\hline $\begin{array}{l}\text { Contact with } \\
\text { ethnic agencies }\end{array}$ & (a) & $\begin{array}{c}-0.029 \\
(0.16)\end{array}$ & $\begin{array}{r}-0.040 \\
(0.22)\end{array}$ & (a) & $\begin{array}{r}-0.043 \\
(0.20)\end{array}$ & $\begin{array}{c}-0.041 \\
(0.19)\end{array}$ \\
\hline $\begin{array}{l}\text { Expect to leave } \\
\text { Australia }\end{array}$ & (a) & $\begin{array}{l}0.173 \\
(1.11)\end{array}$ & $\begin{array}{l}0.126 \\
(0.79)\end{array}$ & (a) & $\begin{array}{l}0.036 \\
(0.18)\end{array}$ & $\begin{array}{l}0.028 \\
(0.14)\end{array}$ \\
\hline $\begin{array}{l}\text { Birthplace } \\
\text { concentration }\end{array}$ & (a) & $\begin{array}{l}-0.018 \\
(2.59)\end{array}$ & $\begin{array}{l}-0.021 \\
(2.74)\end{array}$ & (a) & $\begin{array}{r}-0.043 \\
(5.30)\end{array}$ & $\begin{array}{l}-0.048 \\
(5.41)\end{array}$ \\
\hline Distance/1000 & (a) & $\begin{array}{r}-0.134 \\
(1.76)\end{array}$ & $\begin{array}{r}-0.082 \\
(0.78)\end{array}$ & (a) & $\begin{array}{l}-0.242 \\
(2.84)\end{array}$ & $\begin{array}{r}-0.085 \\
(0.75)\end{array}$ \\
\hline Distance $^{2} / 1 \mathrm{~m}$ & (a) & $\begin{array}{l}0.008 \\
(2.39)\end{array}$ & $\begin{array}{l}0.003 \\
(0.58)\end{array}$ & (a) & $\begin{array}{l}0.014 \\
(3.56)\end{array}$ & $\begin{array}{l}0.005 \\
(0.89)\end{array}$ \\
\hline Linguistic distance & (a) & $\begin{array}{r}-0.312 \\
(1.09)\end{array}$ & $\begin{array}{l}0.310 \\
(0.74)\end{array}$ & (a) & $\begin{array}{r}-0.247 \\
(0.77)\end{array}$ & $\begin{array}{l}0.161 \\
(0.34)\end{array}$ \\
\hline $\begin{array}{l}\text { Family Structure } \\
\text { MUS }^{(\mathrm{c})}\end{array}$ & $\begin{array}{l}-0.307 \\
(3.05)\end{array}$ & $\begin{array}{l}-0.304 \\
(2.90)\end{array}$ & $\begin{array}{l}-0.270 \\
(2.53)\end{array}$ & $\begin{array}{l}-0.237 \\
(2.00)\end{array}$ & $\begin{array}{l}-0.410 \\
(3.26)\end{array}$ & $\begin{array}{l}-0.379 \\
(2.98)\end{array}$ \\
\hline $\mathrm{OS}^{(\mathrm{d})}$ & $\begin{array}{l}-0.280 \\
(3.00)\end{array}$ & $\begin{array}{r}-0.160 \\
(1.57)\end{array}$ & $\begin{array}{r}-0.198 \\
(1.93)\end{array}$ & $\begin{array}{l}-0.088 \\
(0.92)\end{array}$ & $\begin{array}{r}-0.226 \\
(2.11)\end{array}$ & $\begin{array}{l}-0.271 \\
(2.51)\end{array}$ \\
\hline $\operatorname{KIDS}^{(\mathrm{e})}$ & $\begin{array}{l}-0.249 \\
(3.88)\end{array}$ & $\begin{array}{c}-0.326 \\
(4.81)\end{array}$ & $\begin{array}{c}-0.296 \\
(4.25)\end{array}$ & $\begin{array}{l}-0.157 \\
(2.06)\end{array}$ & $\begin{array}{r}-0.155 \\
(1.92)\end{array}$ & $\begin{array}{l}-0.159 \\
(1.89)\end{array}$ \\
\hline $\operatorname{MUR}^{(\mathrm{f})}$ & $\begin{array}{l}0.022 \\
(0.14)\end{array}$ & $\begin{array}{c}-0.226 \\
(1.36)\end{array}$ & $\begin{array}{r}-0.113 \\
(0.67)\end{array}$ & $\begin{array}{l}0.806 \\
(4.02)\end{array}$ & $\begin{array}{l}0.615 \\
(2.87)\end{array}$ & $\begin{array}{l}0.693 \\
(3.22)\end{array}$ \\
\hline
\end{tabular}




\begin{tabular}{lccc|ccc}
$\mathrm{OR}^{(\mathrm{g})}$ & -0.371 & -0.336 & -0.268 & -0.151 & -0.127 & -0.091 \\
& $(5.62)$ & $(4.75)$ & $(3.71)$ & $(2.00)$ & $(1.54)$ & $(1.09)$ \\
$\chi^{2}$ & 1111.55 & 1393.37 & 1475.15 & 744.27 & 1016.50 & 1071.67 \\
$\begin{array}{l}\text { Prediction success } \\
\text { rate (\%) }\end{array}$ & 77.37 & 78.77 & 79.32 & 80.58 & 81.87 & 82.32 \\
$\begin{array}{l}\text { Sample size } \\
\text { (h) }\end{array}$ & 2930 & 2930 & 2930 & 2410 & 2410 & 2410 \\
\hline
\end{tabular}

Note: Numbers in parentheses are ' $t$ ' statistics.

${ }^{(a)}$ Variable not entered.

(b) ENS denotes Employer Nomination Scheme.

${ }^{(c)}$ Whether a spouse who was part of the migrating unit is present in the household.

${ }^{\text {(d) }}$ Whether a spouse who was not part of the migrating unit is present in the household.

${ }^{(e)}$ Whether children in the household.

(f) Whether other relatives who gained approval to migrate to Australia as part of the Principal Applicant's migration application are present in the household.

${ }^{(g)}$ Whether other relatives are present in the household.

${ }^{\text {(h) }}$ For wave 2 he total number of cases is 2930 . These data are weighted using sample weights to reflect a population of 45534 . For wave 3 the total number of cases is 2410 . The wave 3 data are weighted using sample weights to reflect a population of 42545 .

The benchmark group defined by the omitted categorical variables is male immigrants from Southern Europe who entered Australia under Independent visas, did not report cross country/culture in the former home country, did not visit Australia prior to migration, chose their initial State settled for reasons other than Family/Friends, did not have post-immigration contact with ethnic agencies and do not expect to leave Australia.

Source: Longitudinal Survey of Immigrants to Australia (Waves Two and Three) 
TABLE 7: Probit Models of English Reading and Writing Skills, 15-64 Year Old Males and Females from Non-English Speaking Countries, Waves One, Two and Three

\begin{tabular}{|c|c|c|c|c|c|c|}
\hline \multirow[b]{2}{*}{ Variable } & \multicolumn{3}{|c|}{ Reading Proficiency } & \multicolumn{3}{|c|}{ Writing Proficiency } \\
\hline & Wave 1 & Wave 2 & Wave 3 & Wave 1 & Wave 2 & Wave 3 \\
\hline Constant & $\begin{array}{l}-1.787 \\
(2.68)\end{array}$ & $\begin{array}{l}-0.336 \\
(0.45)\end{array}$ & $\begin{array}{l}1.083 \\
(1.20)\end{array}$ & $\begin{array}{l}-2.779 \\
(4.35)\end{array}$ & $\begin{array}{l}-1.215 \\
(1.74)\end{array}$ & $\begin{array}{r}-0.774 \\
(1.04)\end{array}$ \\
\hline $\begin{array}{l}\text { Visa Category } \\
\text { Humanitarian } \\
\text { (Refugee) }\end{array}$ & $\begin{array}{l}-0.576 \\
(3.92)\end{array}$ & $\begin{array}{l}-0.704 \\
(3.90)\end{array}$ & $\begin{array}{l}-0.450 \\
(2.07)\end{array}$ & $\begin{array}{l}-0.516 \\
(3.92)\end{array}$ & $\begin{array}{l}-0.625 \\
(4.35)\end{array}$ & $\begin{array}{c}-0.604 \\
(3.75)\end{array}$ \\
\hline $\begin{array}{l}\text { Preferential } \\
\text { Family }\end{array}$ & $\begin{array}{l}-0.084 \\
(0.52)\end{array}$ & $\begin{array}{l}-0.439 \\
(2.30)\end{array}$ & $\begin{array}{l}-0.554 \\
(2.52)\end{array}$ & $\begin{array}{l}-0.249 \\
(1.69)\end{array}$ & $\begin{array}{l}-0.722 \\
(4.70)\end{array}$ & $\begin{array}{c}-0.268 \\
(1.66)\end{array}$ \\
\hline $\begin{array}{l}\text { Concessional } \\
\text { Family }\end{array}$ & $\begin{array}{l}-0.388 \\
(2.38)\end{array}$ & $\begin{array}{l}-0.621 \\
(3.16)\end{array}$ & $\begin{array}{l}-0.553 \\
(2.35)\end{array}$ & $\begin{array}{l}-0.363 \\
(2.58)\end{array}$ & $\begin{array}{l}-0.491 \\
(3.13)\end{array}$ & $\begin{array}{l}-0.540 \\
(3.15)\end{array}$ \\
\hline $\begin{array}{l}\text { Business } \\
\text { Skills/ENS }\end{array}$ & $\begin{array}{l}-0.478 \\
(2.11)\end{array}$ & $\begin{array}{l}-0.437 \\
(1.54)\end{array}$ & $\begin{array}{l}-0.751 \\
(2.34)\end{array}$ & $\begin{array}{l}-0.219 \\
(1.08)\end{array}$ & $\begin{array}{l}-0.288 \\
(1.20)\end{array}$ & $\begin{array}{l}-0.554 \\
(2.16)\end{array}$ \\
\hline Age at migration & $\begin{array}{l}-0.018 \\
(5.54)\end{array}$ & $\begin{array}{l}-0.014 \\
(4.33)\end{array}$ & $\begin{array}{l}-0.032 \\
(7.86)\end{array}$ & $\begin{array}{l}-0.021 \\
(6.34)\end{array}$ & $\begin{array}{l}-0.013 \\
(3.97)\end{array}$ & $\begin{array}{l}-0.028 \\
(7.36)\end{array}$ \\
\hline Education & $\begin{array}{c}0.233 \\
(20.80)\end{array}$ & $\begin{array}{c}0.227 \\
(20.07)\end{array}$ & $\begin{array}{c}0.202 \\
(15.83)\end{array}$ & $\begin{array}{c}0.224 \\
(19.64)\end{array}$ & $\begin{array}{c}0.196 \\
(17.87)\end{array}$ & $\begin{array}{c}0.198 \\
(16.63)\end{array}$ \\
\hline Female & $\begin{array}{l}-0.176 \\
(2.71)\end{array}$ & $\begin{array}{l}-0.040 \\
(0.57)\end{array}$ & $\begin{array}{l}-0.035 \\
(0.42)\end{array}$ & $\begin{array}{l}-0.056 \\
(0.89)\end{array}$ & $\begin{array}{l}0.093 \\
(1.40)\end{array}$ & $\begin{array}{r}-0.088 \\
(1.20)\end{array}$ \\
\hline $\begin{array}{l}\text { Birthplace } \\
\text { Western Europe }\end{array}$ & $\begin{array}{l}0.973 \\
(5.23)\end{array}$ & $\begin{array}{l}0.887 \\
(3.72)\end{array}$ & $\begin{array}{l}1.047 \\
(3.05)\end{array}$ & $\begin{array}{l}1.073 \\
(6.33)\end{array}$ & $\begin{array}{l}0.656 \\
(3.37)\end{array}$ & $\begin{array}{l}0.843 \\
(3.70)\end{array}$ \\
\hline Northern Europe & $\begin{array}{l}1.044 \\
(3.55)\end{array}$ & $\begin{array}{l}1.340 \\
(2.74)\end{array}$ & $\begin{array}{l}4.936 \\
(0.09)\end{array}$ & $\begin{array}{l}1.126 \\
(4.17)\end{array}$ & $\begin{array}{l}0.477 \\
(1.63)\end{array}$ & $\begin{array}{l}1.115 \\
(2.57)\end{array}$ \\
\hline Eastern Europe & $\begin{array}{l}-0.040 \\
(0.24)\end{array}$ & $\begin{array}{l}-0.049 \\
(0.27)\end{array}$ & $\begin{array}{l}0.243 \\
(1.08)\end{array}$ & $\begin{array}{l}-0.110 \\
(0.64)\end{array}$ & $\begin{array}{l}0.008 \\
(0.05)\end{array}$ & $\begin{array}{l}0.122 \\
(0.62)\end{array}$ \\
\hline $\begin{array}{l}\text { The USSR and the } \\
\text { Baltic States }\end{array}$ & $\begin{array}{l}-0.042 \\
(0.27)\end{array}$ & $\begin{array}{l}-0.241 \\
(1.40)\end{array}$ & $\begin{array}{l}0.128 \\
(0.62)\end{array}$ & $\begin{array}{l}-0.064 \\
(0.40)\end{array}$ & $\begin{array}{l}-0.240 \\
(1.49)\end{array}$ & $\begin{array}{l}-0.251 \\
(1.39)\end{array}$ \\
\hline The Middle East & $\begin{array}{l}0.647 \\
(4.31)\end{array}$ & $\begin{array}{l}0.147 \\
(0.88)\end{array}$ & $\begin{array}{l}0.135 \\
(0.68)\end{array}$ & $\begin{array}{l}0.625 \\
(4.17)\end{array}$ & $\begin{array}{l}0.510 \\
(3.28)\end{array}$ & $\begin{array}{l}0.171 \\
(0.97)\end{array}$ \\
\hline North Africa & $\begin{array}{l}0.961 \\
(4.05)\end{array}$ & $\begin{array}{l}-0.023 \\
(0.09)\end{array}$ & $\begin{array}{l}0.168 \\
(0.56)\end{array}$ & $\begin{array}{l}0.973 \\
(4.31)\end{array}$ & $\begin{array}{l}0.605 \\
(2.53)\end{array}$ & $\begin{array}{l}0.367 \\
(1.40)\end{array}$ \\
\hline South East Asia & $\begin{array}{l}0.609 \\
(1.91)\end{array}$ & $\begin{array}{l}-0.379 \\
(1.02)\end{array}$ & $\begin{array}{l}-0.293 \\
(0.66)\end{array}$ & $\begin{array}{l}0.899 \\
(2.92)\end{array}$ & $\begin{array}{l}0.766 \\
(2.29)\end{array}$ & $\begin{array}{l}0.057 \\
(0.15)\end{array}$ \\
\hline
\end{tabular}




\begin{tabular}{|c|c|c|c|c|c|c|}
\hline North East Asia & $\begin{array}{l}0.340 \\
(1.13)\end{array}$ & $\begin{array}{r}-0.674 \\
(1.91)\end{array}$ & $\begin{array}{r}-0.602 \\
(1.43)\end{array}$ & $\begin{array}{l}0.335 \\
(1.15)\end{array}$ & $\begin{array}{l}0.299 \\
(0.94)\end{array}$ & $\begin{array}{r}-0.160 \\
(0.44)\end{array}$ \\
\hline Southern Asia & $\begin{array}{l}0.212 \\
(0.74)\end{array}$ & $\begin{array}{r}-0.303 \\
(0.89)\end{array}$ & $\begin{array}{l}0.140 \\
(0.34)\end{array}$ & $\begin{array}{l}0.616 \\
(2.24)\end{array}$ & $\begin{array}{l}0.585 \\
(1.97)\end{array}$ & $\begin{array}{l}-0.041 \\
(0.12)\end{array}$ \\
\hline $\begin{array}{l}\text { South and Central } \\
\text { America }\end{array}$ & $\begin{array}{l}0.382 \\
(1.80)\end{array}$ & $\begin{array}{l}0.023 \\
(0.09)\end{array}$ & $\begin{array}{l}0.324 \\
(1.10)\end{array}$ & $\begin{array}{l}0.275 \\
(1.32)\end{array}$ & $\begin{array}{l}0.300 \\
(1.32)\end{array}$ & $\begin{array}{l}0.162 \\
(0.62)\end{array}$ \\
\hline $\begin{array}{l}\text { Former British } \\
\text { colony }\end{array}$ & $\begin{array}{l}1.670 \\
(13.54)\end{array}$ & $\begin{array}{l}1.297 \\
(9.98)\end{array}$ & $\begin{array}{l}1.278 \\
(7.92)\end{array}$ & $\begin{array}{l}1.557 \\
(14.40)\end{array}$ & $\begin{array}{c}1.388 \\
(12.03)\end{array}$ & $\begin{array}{l}1.277 \\
(9.75)\end{array}$ \\
\hline $\begin{array}{l}\text { Cross } \\
\text { country/culture } \\
\text { contact in former } \\
\text { home country }\end{array}$ & $\begin{array}{l}0.174 \\
(2.90)\end{array}$ & $\begin{array}{l}0.169 \\
(2.59)\end{array}$ & $\begin{array}{l}0.301 \\
(3.98)\end{array}$ & $\begin{array}{l}0.146 \\
(2.46)\end{array}$ & $\begin{array}{l}0.200 \\
(3.20)\end{array}$ & $\begin{array}{l}0.228 \\
(3.37)\end{array}$ \\
\hline $\begin{array}{l}\text { Previously visited } \\
\text { Australia }\end{array}$ & $\begin{array}{l}0.530 \\
(6.60)\end{array}$ & $\begin{array}{l}0.192 \\
(2.14)\end{array}$ & $\begin{array}{l}0.269 \\
(2.50)\end{array}$ & $\begin{array}{l}0.439 \\
(5.81)\end{array}$ & $\begin{array}{l}0.302 \\
(3.67)\end{array}$ & $\begin{array}{l}0.201 \\
(2.22)\end{array}$ \\
\hline $\begin{array}{l}\text { Main Reason for } \\
\text { choosing State } \\
\text { settled was } \\
\text { Family/Friends }\end{array}$ & $\begin{array}{l}-0.118 \\
(1.31)\end{array}$ & $\begin{array}{l}-0.149 \\
(1.50)\end{array}$ & $\begin{array}{l}0.115 \\
(0.99)\end{array}$ & $\begin{array}{l}-0.022 \\
(0.26)\end{array}$ & $\begin{array}{l}-0.111 \\
(1.22)\end{array}$ & $\begin{array}{l}-0.087 \\
(0.85)\end{array}$ \\
\hline $\begin{array}{l}\text { Contact with ethnic } \\
\text { agencies }\end{array}$ & $\begin{array}{l}-0.046 \\
(0.68)\end{array}$ & $\begin{array}{l}-0.245 \\
(1.25)\end{array}$ & $\begin{array}{l}-0.310 \\
(1.41)\end{array}$ & $\begin{array}{l}-0.116 \\
(1.74)\end{array}$ & $\begin{array}{l}0.131 \\
(0.70)\end{array}$ & $\begin{array}{l}-0.230 \\
(1.08)\end{array}$ \\
\hline $\begin{array}{l}\text { Expect to leave } \\
\text { Australia }\end{array}$ & $\begin{array}{l}-0.230 \\
(1.61)\end{array}$ & $\begin{array}{l}0.016 \\
(0.09)\end{array}$ & $\begin{array}{l}0.144 \\
(0.59)\end{array}$ & $\begin{array}{l}-0.070 \\
(0.50)\end{array}$ & $\begin{array}{l}-0.023 \\
(0.15)\end{array}$ & $\begin{array}{l}-0.158 \\
(0.84)\end{array}$ \\
\hline $\begin{array}{l}\text { Birthplace } \\
\text { concentration }\end{array}$ & $\begin{array}{l}-0.015 \\
(2.02)\end{array}$ & $\begin{array}{r}-0.011 \\
(1.58)\end{array}$ & $\begin{array}{l}-0.024 \\
(3.09)\end{array}$ & $\begin{array}{l}-0.017 \\
(2.19)\end{array}$ & $\begin{array}{r}-0.030 \\
(4.04)\end{array}$ & $\begin{array}{l}-0.015 \\
(1.88)\end{array}$ \\
\hline Distance/1000 & $\begin{array}{l}-0.084 \\
(0.89)\end{array}$ & $\begin{array}{r}-0.152 \\
(1.40)\end{array}$ & $\begin{array}{l}-0.442 \\
(3.34)\end{array}$ & $\begin{array}{l}0.039 \\
(0.43)\end{array}$ & $\begin{array}{r}-0.154 \\
(1.54)\end{array}$ & $\begin{array}{l}-0.108 \\
(1.01)\end{array}$ \\
\hline Distance $^{2} / 1 \mathrm{~m}$. & $\begin{array}{l}0.005 \\
(1.12)\end{array}$ & $\begin{array}{l}0.005 \\
(1.02)\end{array}$ & $\begin{array}{l}0.019 \\
(3.01)\end{array}$ & $\begin{array}{l}0.000 \\
(0.04)\end{array}$ & $\begin{array}{l}0.010 \\
(2.19)\end{array}$ & $\begin{array}{l}0.005 \\
(1.00)\end{array}$ \\
\hline Linguistic distance & $\begin{array}{l}-0.661 \\
(1.63)\end{array}$ & $\begin{array}{l}0.236 \\
(0.56)\end{array}$ & $\begin{array}{l}1.134 \\
(2.39)\end{array}$ & $\begin{array}{l}-0.588 \\
(1.50)\end{array}$ & $\begin{array}{l}-0.696 \\
(1.67)\end{array}$ & $\begin{array}{l}0.231 \\
(0.52)\end{array}$ \\
\hline $\begin{array}{l}\text { Family structure } \\
\text { MUS }^{(\mathrm{c})}\end{array}$ & $\begin{array}{l}-0.225 \\
(2.22)\end{array}$ & $\begin{array}{r}-0.306 \\
(2.79)\end{array}$ & $\begin{array}{l}-0.092 \\
(0.69)\end{array}$ & $\begin{array}{l}-0.203 \\
(2.02)\end{array}$ & $\begin{array}{r}-0.344 \\
(3.26)\end{array}$ & $\begin{array}{r}-0.330 \\
(2.74)\end{array}$ \\
\hline $\mathrm{OS}^{(\mathrm{d})}$ & $\begin{array}{r}-0.529 \\
(4.87)\end{array}$ & $\begin{array}{c}-0.363 \\
(3.53)\end{array}$ & $\begin{array}{l}-0.024 \\
(0.21)\end{array}$ & $\begin{array}{l}-0.286 \\
(2.67)\end{array}$ & $\begin{array}{c}-0.078 \\
(0.78)\end{array}$ & $\begin{array}{r}-0.373 \\
(3.67)\end{array}$ \\
\hline $\operatorname{KIDS}^{(\mathrm{e})}$ & $\begin{array}{r}-0.107 \\
(1.48)\end{array}$ & $\begin{array}{c}-0.234 \\
(3.33)\end{array}$ & $\begin{array}{c}-0.303 \\
(3.35)\end{array}$ & $\begin{array}{l}-0.164 \\
(2.29)\end{array}$ & $\begin{array}{c}-0.258 \\
(3.79)\end{array}$ & $\begin{array}{l}-0.045 \\
(0.57)\end{array}$ \\
\hline
\end{tabular}




\begin{tabular}{lccc:ccc} 
MUR $^{(\mathrm{f})}$ & 0.196 & 0.315 & -0.182 & 0.256 & 0.058 & 0.729 \\
& $(1.22)$ & $(1.78)$ & $(0.90)$ & $(1.58)$ & $(0.34)$ & $(3.50)$ \\
$\mathrm{OR}^{(\mathrm{g})}$ & -0.169 & -0.111 & -0.277 & -0.193 & -0.120 & -0.129 \\
& $(2.51)$ & $(1.51)$ & $(3.19)$ & $(2.89)$ & $(1.68)$ & $(1.62)$ \\
$\chi^{2}$ & 1935.64 & 1207.11 & 868.14 & 2075.66 & 1445.49 & 1085.54 \\
$\begin{array}{l}\text { Prediction success } \\
\text { rate }(\%)\end{array}$ & 81.69 & 83.32 & 85.53 & 79.37 & 78.16 & 78.57 \\
$\begin{array}{l}\text { Sample size } \\
\text { Sh) }\end{array}$ & 3414 & 2931 & 2343 & 3418 & 2931 & 2413 \\
\hline
\end{tabular}

Note: Numbers in parentheses are ' $t$ ' statistics.

${ }^{(a)}$ Variable not entered.

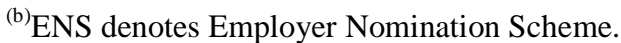

${ }^{(c)}$ Whether a spouse who was part of the migrating unit is present in the household.

${ }^{(d)}$ Whether a spouse who was not part of the migrating unit is present in the household.

${ }^{(\mathrm{e})}$ Whether children in the household.

${ }^{(f)}$ Whether other relatives who gained approval to migrate to Australia as part of the Principal Applicant's migration application are present in the household.

${ }^{(\mathrm{g})}$ Whether other relatives are present in the household.

(h) The total number of cases for the wave 1 reading and writing analyses are 3414 and 3418, respectively. The data are weighted using sample weights to reflect a population of 48495 and 48463 , respectively. For the wave 2 analyses the total number of cases is 2931 . The wave 2 data are weighted using sample weights to reflect a population of 45565. The total number of cases in analysing the reading and writing proficiencies are 2343 and 2413, respectively. The data are weighted using sample weights to reflect a population of 41263 and 42616, respectively.

The benchmark group defined by the omitted categorical variables is male immigrants from Southern Europe who entered Australia under Independent visas, did not report cross country/culture in the former home country, did not visit Australia prior to migration, chose their initial State settled for reasons other than Family/Friends, did not have post-immigration contact with ethnic agencies and do not expect to leave Australia.

Source: Longitudinal Survey of Immigrants to Australia (Waves One, Two and Three) 
TABLE 8: Estimates of Correlation Coefficient from Bivariate Probit Models of English Speaking, Reading and Writing Skills, 15-64 Year Old Males and Females from Non-English Speaking Countries,

\begin{tabular}{lccc}
\hline \multirow{2}{*}{ Skills } & \multicolumn{3}{c}{ Correlation Coefficients, $\rho$} \\
\cline { 2 - 4 } Speaking & Wave1-Wave2 & Wave2-Wave3 & Wave1-Wave3 \\
\cline { 2 - 4 } & 0.854 & 0.790 & 0.728 \\
\multirow{2}{*}{ Reading } & $(54.90)$ & $(41.00)$ & $(30.11)$ \\
& 0.738 & 0.826 & 0.623 \\
\multirow{2}{*}{ Writing } & $(26.46)$ & $(37.41)$ & $(16.59)$ \\
& 0.755 & 0.812 & 0.673 \\
Sample size & $(27.73)$ & $(36.45)$ & $(20.78)$ \\
& 2304 & 2304 & 2304 \\
\hline
\end{tabular}

Note: Numbers in parentheses are ' $t$ ' statistics. The specification of the models is given in Appendix C, Table C1.

Source: Longitudinal Survey of Immigrants to Australia (Wave One, Wave Two and Wave Three) 


\section{REFERENCES}

Amemiya, Takashi (1981). "Qualitative Response Models: A Survey”, Journal of Economic Literature, Vol.19, pp. 1483-1536.

Australian Bureau of Statistics (1993) CDATA91 with Mapinfo: 1991 Census of Population and Housing (Australia), Greenwich, New South Wales: Peripheral Systems, Canberra: Australian Bureau of Statistics.

Beenstock, Michael (1996). "The Acquisition of Language Skills by Immigrants: The Case of Hebrew in Israel", International Migration, Vol. 34, No. 1, pp. 3-28.

Borjas, George J. (1985). “Assimilation, Changes in Cohort Quality, and the Earnings of Immigrants", Journal of Labor Economics, Vol. 3, No. 4, pp. 463-489.

Chiswick, Barry R. (1980). An Analysis of the Economic Progress and Impact of Immigrants, National Technical Information Services, NTIS No. PB80200454, August.

Chiswick, Barry R. (1998). "Hebrew Language Usage: Determinants and Effects on Earnings among Immigrants in Israel", Journal of Population Economics, Vol. 11, No. 2, pp. 253-271.

Chiswick, Barry R. and Paul W. Miller (1992). "Language in the Labor Market: The Immigrant Experience in Canada and the United States", in Barry R. Chiswick (ed.) Immigration, Language and Ethnic Issues: Canada and the United States, Washington, DC: American Enterprise Institute, pp. 229-296.

Chiswick, Barry R. and Paul W. Miller (1994). "Language Choice Among Immigrants in a Multi-Lingual Destination", Journal of Population Economics, Vol. 7, No. 2, pp. 119-131.

Chiswick, Barry R. and Paul W. Miller (1995). "The Endogeneity Between Language and Earnings: International Analyses", Journal of Labor Economics, Vol. 13, No. 2, pp. 246-288.

Chiswick, Barry R. and Paul W. Miller (1996). "Ethnic Networks and Language Proficiency Among Immigrants", Journal of Population Economics, Vol. 9, pp. 19-35.

Chiswick, Barry R. and Paul W. Miller (1998a). "English Language Fluency Among Immigrants in the United States", Research in Labor Economics, Vol. 17, pp. 151-200.

Chiswick, Barry R. and Paul W. Miller (1998b). "Language Skill Definition: A Study of Legalized Aliens", International Migration Review, Vol. 32, No. 4, pp. 877900 . 
Chiswick, Barry R. and Paul W. Miller (1999). "Immigration, Language and Multiculturalism in Australia", Australian Economic Review, Vol. 32, No. 4, pp. 369-385.

Chiswick, Barry R. and Paul W. Miller (2001). "A Model of Destination Language Acquisition: Application to Male Immigrants in Canada", Demography Vol. 38, No. 3, pp. 391-409.

Chiswick, Barry R., Yew Liang Lee and Paul W. Miller (2002). “ Family Matters: The Role of the Family in Immigrants' Destination Language Acquisition", photocopied, Department of Economics, The University of Western Australia.

Cobb-Clark, Deborah A. (2000). "Do Selection Criteria Make a Difference? Visa Category and the Labour Market Status of Immigrants to Australia", Economic Record, Vol. 76, No. 232, pp. 15-31.

Dustmann, Christian (1994). "Speaking Fluency, Writing Fluency and Earnings of Migrants", Journal of Population Economics, Vol. 7, No. 2, pp. 226-236.

Evans, M. D. R. (1986). "Sources of Immigrants' Language Proficiency: Australian Results with Comparisons to the Federal Republic of Germany", European Sociological Review, Vol. 2, pp. 226-236.

Fitzpatrick, Gary L. and Marilyn J. Modlin (1986). Direct-line Distances: International Edition, Metuchen, NJ: The Scarecrow Press Inc.

Greene, William H., (1991). Econometric Analysis, New York: Macmillan Publishing Company.

Hart-Gonzalez, Lucinda and Stephanie Lindemann (1993). "Expected Achievement in Speaking Proficiency, 1993”, School of Language Studies, Foreign Services Institute, Department of State, mimeo.

Long, Michael H. (1990). "Maturational Constraints on Language Development", Studies in Second Language Acquisition, Vol. 12, No. 3, pp. 251-285.

Murphy, Jill (1997). Initial Location Decisions of Immigrants, Canberra: Department of Immigration and Multicultural Affairs.

Psacharopoulos, George (1979). "On the Weak Versus the Strong Version of the Screening Hypothesis", Economics Letters, Vol. 4, pp. 181-185.

Service, Elisabet and Fergus I.M. Craik (1993). "Differences Between Young and Older Adults in Learning a Foreign Vocabulary", Journal of Memory and Language, Vol. 32, pp. 608-623. 


\section{APPENDIX A}

\section{DEFINITIONS OF VARIABLES}

The study is based on the Longitudinal Survey of Immigrants to Australia, a sample of Principal Applicant immigrants who arrived in Australia as offshore visaed immigrants in the two-year period of September 1993 to August 1995. The variables used in the statistical analysis are described below. For the statistical analyses, the relevant population is immigrants aged 15-64 years, excluding those from the main English-speaking countries.

\section{Dependent Variables:}

English Speaking Skills: Five levels of English speaking skills are distinguished. They are: (i) English best (or English only); Speaks a language other than English best and speaks English: (ii) Very well; (iii) Well; (iv) Not well; (v) Not at all. In this study the first three categories (denoted "proficient") are distinguished from the remaining categories (denoted "not proficient").

English Reading Skills: Five levels of English reading skills are distinguished. They are: (i) English best (or English only); Speaks a language other than English best and reads English: (ii) Very well; (iii) Well; (iv) Not well; (v) Not at all, or does not speak English at all. ${ }^{28}$ In this study the first three categories (denoted "proficient") are distinguished from the remaining categories (denoted "not proficient").

English Writing Skills: Five levels of English writing skills are distinguished. They are: (i) English best (or English only); Speaks a language other than English best and writes English: (ii) Very well; (iii) Well; (iv) Not well; (v) Not at all, or does not speak English at all. ${ }^{29}$ In this study the first three categories (denoted "proficient") are distinguished from the remaining categories (denoted "not proficient").

\section{Independent Variables:}

Age: This is a continuous variable that measures the individual's age. The analysis is restricted to immigrants aged 15 to 64 years.

Educational Attainment: The continuous "Years of Education" variable was created by assigning years of full-time equivalent education to each of the nine levels of education available. They are: (i) Higher degree (19.5 years); (ii) Postgraduate diploma (17.5 years); (iii) Bachelor degree (16.5 years); (iv) Technical/professional qualification (15 years); (v) Trade (13 years) ; (vi) 12 or more years of schooling (13 years); (vii) 10-11 years (10.5 years); (viii) $7-9$ years (8 years); and (ix) 6 years or less (6 years).

${ }^{28}$ Information on English reading skills was not collected where the individual could not speak English at all. It is assumed that these individuals would not be able to read English

${ }^{29}$ Information on English writing skills was not collected where the individual could not speak English at all. It is assumed that these individuals would not be able to write English 
Gender: Dichotomous variable, equal to unity for females.

Birthplace: Fourteen birthplace regions are distinguished, namely (i) UK and Ireland; (ii) Southern Europe; (iii) Western Europe; (iv) Northern Europe; (v) Eastern Europe; (vi) The USSR and the Baltic States; (vii) The Middle East; (viii) North Africa; (ix) Southeast Asia; (x) Northeast Asia; (xi) Southern Asia; (xii) North America; (xiii) South and Central America, including Mexico; (xiv) Caribbean, Central and West Africa, and Southern and East Africa. The analysis is restricted to non-English speaking countries (i.e., immigrants from UK and Ireland, North America and South Africa are excluded). The region of Caribbean, Central and West Africa, and Southern and East Africa has been excluded from the analysis as insufficient immigrants are represented to permit construction of some of the auxiliary regressors employed in the analysis. Southern Europe is used as the benchmark group in the analysis. Note that immigrants from New Zealand are not included in the survey. An additional birthplace dichotomous variable is set equal to unity for birthplaces that are former British colonies.

Culture/Country Contact: Dichotomous variable equal to unity if the immigrant had cross culture/country contact in their former home country.

Visit to Australia: Dichotomous variable equal to unity for those from migrating units where the PA visited Australia prior to migrating.

Reason for Choice of State: Dichotomous variable equal to unity when family and friends were the main reason for choosing the initial State/Territory settled.

Ethnic Agencies Contact: Dichotomous variable for when the recent arrival had post-immigrant contact with an ethnic organisation, religious organisation, or voluntary welfare agency.

Emigration: Dichotomous variable equal to unity for PAs who expect to return to their former home country or to emigrate to another country.

Birthplace Concentration: The percentage of those in the immigrant's region of residence, measured at the postcode level, born in the same country or region as the immigrant. $^{30}$

Distance: The kilometres between the major city in the immigrant's country of origin and the capital city of the wave one Australian State/Territory of residence. ${ }^{31}$

Language Distance: This variable is constructed from a measure of the difficulty of learning a foreign language for English-speaking Americans. It is based on a set of

\footnotetext{
30 The birthplace concentration data are from the 1991 Australian Census of Population and Housing (see Australian Bureau of Statistics (1993)).

31 These data are from Fitzpatrick and Modlin's (1986) Direct Line Distances, International Edition.
} 
language scores (LS) measuring achievements in speaking proficiency by Englishspeaking Americans at the U.S. Department of State, School of Language Studies, reported by Hart-Gonzalez and Lindermann (1993). For the same number of weeks of instruction, a lower score (LS) represents less language facility, and, it is assumed, greater linguistic distance between English and the specific foreign language. For example, Italian is scored at 2.5 (in a range from one to three) and Arabic is scored at 1.5. This methodology assumes symmetry across languages, that is, if a language is difficult for English-speaking Americans to learn, it is equally difficult for native speakers of that language to learn English.

Visa Group: Five visa groups are identified by dichotomous variables in the analysis: (i) Preferential Family; (ii) Concessional Family; (iii) Business Skills and Employer Nomination; (iv) Independent; and (v) Humanitarian. The benchmark group in the regression analysis is Independent.

Family Structure: In the specification where dichotomous variables are used, five variables relating to family structure are distinguished. They are unity: (i) if a spouse who was part of the migrating unit is present in the household (MUS); (ii) if a spouse who was not part of the migrating unit is present in the household (OS); (iii) if there are children in the household (KIDS); (iv) if other relatives who gained approval to migrate to Australia as part of the Principal Applicant's migration application are present in the household (MUR); and (v) if other relatives are present in the household (OR). 
TABLE A1: Means and Standard Deviations of Variables, 15-64 Year Old Males and Females from Non-English Speaking Countries

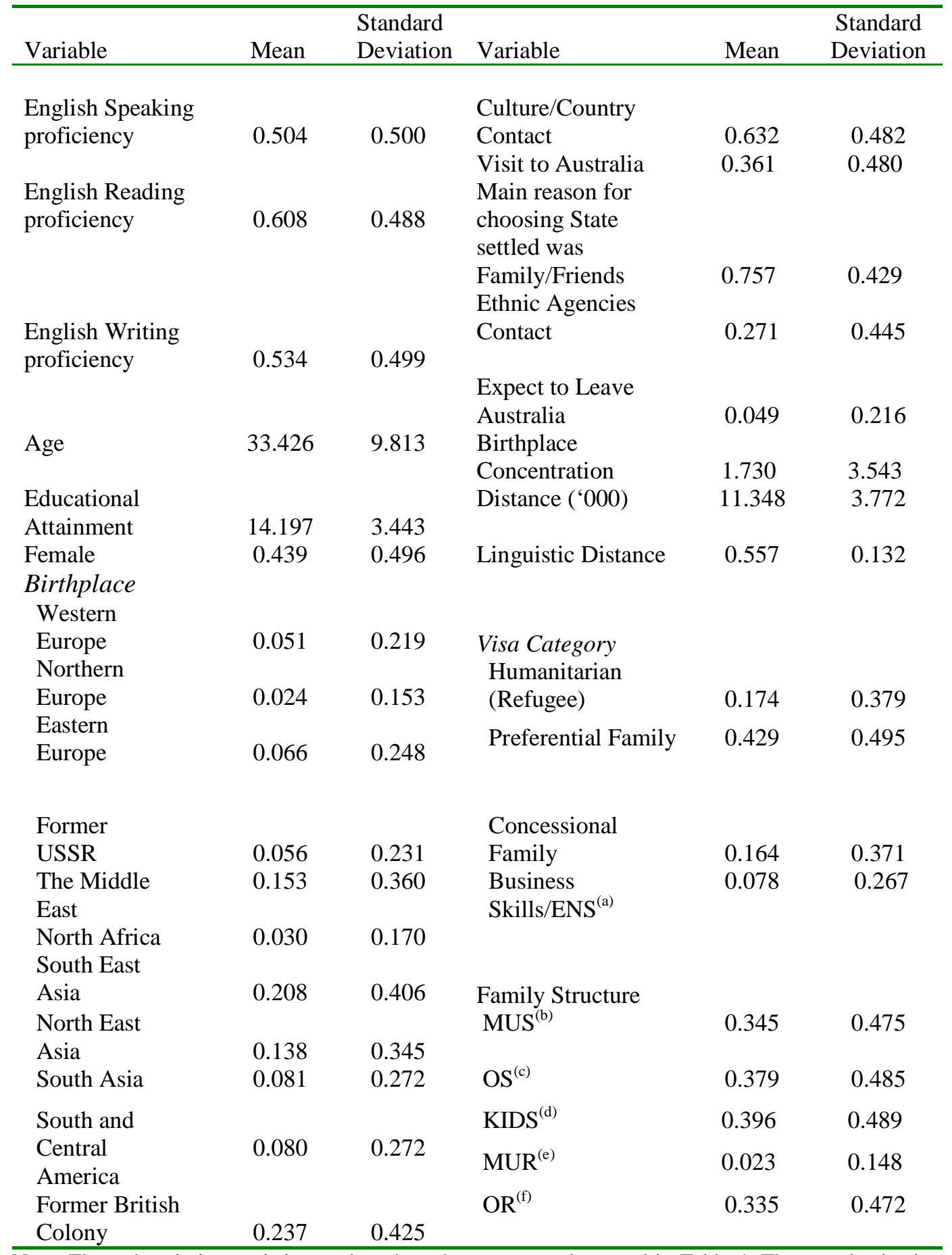

Note: These descriptive statistics are based on the wave one data used in Table 4. The sample size is 3418 , which when weighted using sample weights reflect a population of 48463 .

(a) ENS denotes Employer Nomination Scheme.

(b) Whether a spouse who was part of the migrating unit is present in the household.

${ }^{\text {(c) }}$ Whether a spouse who was not part of the migrating unit is present in the household.

${ }^{\text {(d) }}$ Whether children in the household. 
(e) Whether other relatives who gained approval to migrate to Australia as part of the Principal Applicant's migration application are present in the household.

${ }^{(f)}$ Whether other relatives are present in the household.

Source: Longitudinal Survey of Immigrants to Australia (Wave One). 


\section{APPENDIX B}

TABLE B1: Probit Models of English Speaking Skills by Gender, 15-64 Year Old Males and Females from Non-English Speaking Countries

\begin{tabular}{|c|c|c|c|c|c|c|}
\hline \multirow[t]{2}{*}{ Variable } & \multicolumn{3}{|c|}{ Males } & \multicolumn{3}{|c|}{ Females } \\
\hline & (1) & (2) & (3) & (1) & (2) & (3) \\
\hline Constant & $\begin{array}{l}-1.932 \\
(6.70)\end{array}$ & $\begin{array}{r}-1.379 \\
(2.57)\end{array}$ & $\begin{array}{l}-4.362 \\
(4.68)\end{array}$ & $\begin{array}{l}-0.866 \\
(1.97)\end{array}$ & $\begin{array}{l}0.849 \\
(1.39)\end{array}$ & $\begin{array}{c}-2.684 \\
(2.57)\end{array}$ \\
\hline Visa Category & & & & & & \\
\hline $\begin{array}{l}\text { Humanitarian } \\
\text { (Refugee) }\end{array}$ & $\begin{array}{l}-1.237 \\
(8.63)\end{array}$ & $\begin{array}{l}-0.759 \\
(5.63)\end{array}$ & $\begin{array}{l}-0.834 \\
(5.40)\end{array}$ & $\begin{array}{l}-2.144 \\
(6.96)\end{array}$ & $\begin{array}{l}-1.284 \\
(4.15)\end{array}$ & $\begin{array}{r}-1.426 \\
(4.20)\end{array}$ \\
\hline $\begin{array}{l}\text { Preferential } \\
\text { Family }\end{array}$ & $\begin{array}{l}-0.562 \\
(3.56)\end{array}$ & $\begin{array}{l}-0.418 \\
(2.51)\end{array}$ & $\begin{array}{l}-0.475 \\
(2.72)\end{array}$ & $\begin{array}{l}-0.975 \\
(3.33)\end{array}$ & $\begin{array}{l}-0.653 \\
(2.09)\end{array}$ & $\begin{array}{l}-0.824 \\
(2.43)\end{array}$ \\
\hline $\begin{array}{l}\text { Concessional } \\
\text { Family }\end{array}$ & $\begin{array}{l}-0.535 \\
(3.77)\end{array}$ & $\begin{array}{l}-0.495 \\
(3.47)\end{array}$ & $\begin{array}{l}-0.550 \\
(3.66)\end{array}$ & $\begin{array}{l}-0.959 \\
(3.07)\end{array}$ & $\begin{array}{l}-0.731 \\
(2.18)\end{array}$ & $\begin{array}{r}-0.973 \\
(2.70)\end{array}$ \\
\hline $\begin{array}{l}\text { Business } \\
\text { Skills/ENS }\end{array}$ & $\begin{array}{l}-0.250 \\
(1.22)\end{array}$ & $\begin{array}{l}-0.176 \\
(0.83)\end{array}$ & $\begin{array}{l}-0.114 \\
(0.51)\end{array}$ & $\begin{array}{l}-1.391 \\
(2.56)\end{array}$ & $\begin{array}{l}-0.968 \\
(1.83)\end{array}$ & $\begin{array}{r}-1.124 \\
(1.97)\end{array}$ \\
\hline Age at migration & $\begin{array}{l}-0.008 \\
(1.95)\end{array}$ & $\begin{array}{l}-0.015 \\
(3.48)\end{array}$ & $\begin{array}{l}-0.016 \\
(3.46)\end{array}$ & $\begin{array}{l}-0.008 \\
(1.69)\end{array}$ & $\begin{array}{l}-0.016 \\
(3.42)\end{array}$ & $\begin{array}{l}-0.011 \\
(2.22)\end{array}$ \\
\hline Education & $\begin{array}{c}0.208 \\
(15.06)\end{array}$ & $\begin{array}{c}0.179 \\
(13.05)\end{array}$ & $\begin{array}{c}0.198 \\
(13.34)\end{array}$ & $\begin{array}{c}0.220 \\
(15.10)\end{array}$ & $\begin{array}{c}0.183 \\
(11.54)\end{array}$ & $\begin{array}{r}0.219 \\
(12.11)\end{array}$ \\
\hline $\begin{array}{l}\text { Birthplace } \\
\text { Western Europe }\end{array}$ & $\begin{array}{l}1.401 \\
(5.91)\end{array}$ & (a) & $\begin{array}{l}1.192 \\
(4.83)\end{array}$ & $\begin{array}{l}2.639 \\
(4.35)\end{array}$ & (a) & $\begin{array}{l}2.716 \\
(4.66)\end{array}$ \\
\hline Northern Europe & $\begin{array}{l}1.939 \\
(3.65)\end{array}$ & (a) & $\begin{array}{l}1.734 \\
(3.10)\end{array}$ & $\begin{array}{l}2.097 \\
(3.22)\end{array}$ & (a) & $\begin{array}{l}2.222 \\
(3.13)\end{array}$ \\
\hline Eastern Europe & $\begin{array}{l}-0.524 \\
(2.23)\end{array}$ & (a) & $\begin{array}{l}-0.350 \\
(1.46)\end{array}$ & $\begin{array}{l}-0.696 \\
(2.59)\end{array}$ & (a) & $\begin{array}{r}-0.697 \\
(2.52)\end{array}$ \\
\hline $\begin{array}{l}\text { The USSR \& the } \\
\text { Baltic States }\end{array}$ & $\begin{array}{l}-0.351 \\
(1.69)\end{array}$ & (a) & $\begin{array}{l}-0.168 \\
(0.80)\end{array}$ & $\begin{array}{l}-0.864 \\
(3.11)\end{array}$ & (a) & $\begin{array}{r}-0.989 \\
(3.39)\end{array}$ \\
\hline The Middle East & $\begin{array}{l}-0.076 \\
(0.62)\end{array}$ & (a) & $\begin{array}{l}0.459 \\
(2.37)\end{array}$ & $\begin{array}{c}-0.166 \\
(0.79)\end{array}$ & (a) & $\begin{array}{c}-0.371 \\
(1.31)\end{array}$ \\
\hline North Africa & $\begin{array}{l}0.346 \\
(1.49)\end{array}$ & (a) & $\begin{array}{l}0.879 \\
(3.04)\end{array}$ & $\begin{array}{l}-0.313 \\
(1.01)\end{array}$ & (a) & $\begin{array}{c}-0.315 \\
(0.84)\end{array}$ \\
\hline South East Asia & $\begin{array}{l}0.456 \\
(3.75)\end{array}$ & (a) & $\begin{array}{l}1.375 \\
(3.46)\end{array}$ & $\begin{array}{l}0.663 \\
(3.67)\end{array}$ & (a) & $\begin{array}{c}-0.379 \\
(0.68)\end{array}$ \\
\hline North East Asia & $\begin{array}{l}-0.116 \\
(0.84)\end{array}$ & (a) & $\begin{array}{l}0.457 \\
(1.20)\end{array}$ & $\begin{array}{c}-0.139 \\
(0.71)\end{array}$ & (a) & $\begin{array}{c}-1.402 \\
(2.59)\end{array}$ \\
\hline
\end{tabular}




\begin{tabular}{|c|c|c|c|c|c|c|}
\hline Southern Asia & $\begin{array}{l}1.150 \\
(6.59)\end{array}$ & (a) & $\begin{array}{l}0.855 \\
(2.41)\end{array}$ & $\begin{array}{l}-0.648 \\
(2.97)\end{array}$ & (a) & $\begin{array}{l}-1.710 \\
(3.47)\end{array}$ \\
\hline $\begin{array}{l}\text { South and Central } \\
\text { America }\end{array}$ & $\begin{array}{l}-0.379 \\
(1.70)\end{array}$ & (a) & $\begin{array}{r}-0.081 \\
(0.30)\end{array}$ & $\begin{array}{l}-0.251 \\
(0.83)\end{array}$ & (a) & $\begin{array}{l}-0.645 \\
(1.69)\end{array}$ \\
\hline $\begin{array}{l}\text { Former British } \\
\text { colony }\end{array}$ & (a) & $\begin{array}{c}1.328 \\
(11.50)\end{array}$ & $\begin{array}{l}1.309 \\
(8.92)\end{array}$ & (a) & $\begin{array}{l}1.420 \\
(11.74)\end{array}$ & $\begin{array}{c}1.817 \\
(11.02)\end{array}$ \\
\hline $\begin{array}{l}\text { Cross } \\
\text { country/culture } \\
\text { contact in former } \\
\text { home country }\end{array}$ & (a) & $\begin{array}{l}0.190 \\
(2.51)\end{array}$ & $\begin{array}{l}0.239 \\
(3.02)\end{array}$ & (a) & $\begin{array}{l}0.181 \\
(1.99)\end{array}$ & $\begin{array}{l}0.211 \\
(2.16)\end{array}$ \\
\hline $\begin{array}{l}\text { Previously visited } \\
\text { Australia }\end{array}$ & (a) & $\begin{array}{l}0.581 \\
(6.32)\end{array}$ & $\begin{array}{l}0.611 \\
(5.98)\end{array}$ & (a) & $\begin{array}{l}0.652 \\
(6.22)\end{array}$ & $\begin{array}{l}0.718 \\
(5.73)\end{array}$ \\
\hline $\begin{array}{l}\text { Main reason for } \\
\text { choosing State } \\
\text { settled was } \\
\text { Family/Friends }\end{array}$ & $\begin{array}{l}-0.118 \\
(1.28)\end{array}$ & $\begin{array}{r}-0.170 \\
(1.80)\end{array}$ & $\begin{array}{l}-0.121 \\
(1.24)\end{array}$ & $\begin{array}{l}-0.424 \\
(2.79)\end{array}$ & $\begin{array}{l}-0.266 \\
(1.65)\end{array}$ & $\begin{array}{l}-0.270 \\
(1.53)\end{array}$ \\
\hline $\begin{array}{l}\text { Contact with } \\
\text { ethnic } \\
\text { organisation }\end{array}$ & (a) & $\begin{array}{l}-0.056 \\
(0.69)\end{array}$ & $\begin{array}{l}-0.039 \\
(0.46)\end{array}$ & (a) & $\begin{array}{l}-0.082 \\
(0.79)\end{array}$ & $\begin{array}{c}-0.068 \\
(0.60)\end{array}$ \\
\hline $\begin{array}{l}\text { Expect to leave } \\
\text { Australia }\end{array}$ & (a) & $\begin{array}{l}-0.191 \\
(0.98)\end{array}$ & $\begin{array}{l}-0.266 \\
(1.29)\end{array}$ & (a) & $\begin{array}{l}-0.475 \\
(2.57)\end{array}$ & $\begin{array}{l}-0.602 \\
(2.84)\end{array}$ \\
\hline $\begin{array}{l}\text { Birthplace } \\
\text { concentration }\end{array}$ & (a) & $\begin{array}{l}-0.010 \\
(0.98)\end{array}$ & $\begin{array}{l}-0.024 \\
(2.29)\end{array}$ & (a) & $\begin{array}{l}-0.009 \\
(0.80)\end{array}$ & $\begin{array}{l}-0.025 \\
(1.99)\end{array}$ \\
\hline Distance/1000 & (a) & $\begin{array}{l}0.111 \\
(1.21)\end{array}$ & $\begin{array}{l}0.332 \\
(2.53)\end{array}$ & (a) & $\begin{array}{l}-0.214 \\
(2.17)\end{array}$ & $\begin{array}{l}0.497 \\
(3.43)\end{array}$ \\
\hline Distance $^{2} / 1 \mathrm{~m}$ & (a) & $\begin{array}{r}-0.004 \\
(0.95)\end{array}$ & $\begin{array}{l}-0.010 \\
(1.58)\end{array}$ & (a) & $\begin{array}{l}0.010 \\
(2.10)\end{array}$ & $\begin{array}{l}-0.026 \\
(3.52)\end{array}$ \\
\hline Linguistic distance & (a) & $\begin{array}{l}-1.897 \\
(5.36)\end{array}$ & $\begin{array}{l}-1.149 \\
(1.99)\end{array}$ & (a) & $\begin{array}{l}-1.686 \\
(3.94)\end{array}$ & $\begin{array}{l}-0.604 \\
(0.95)\end{array}$ \\
\hline $\begin{array}{l}\text { Family Structure } \\
\text { MUS }^{(\mathrm{c})}\end{array}$ & $\begin{array}{l}-0.155 \\
(1.29)\end{array}$ & $\begin{array}{l}-0.155 \\
(1.26)\end{array}$ & $\begin{array}{r}-0.131 \\
(1.04)\end{array}$ & $\begin{array}{l}-0.268 \\
(1.42)\end{array}$ & $\begin{array}{l}-0.339 \\
(1.81)\end{array}$ & $\begin{array}{r}-0.339 \\
(1.71)\end{array}$ \\
\hline $\mathrm{OS}^{(\mathrm{d})}$ & $\begin{array}{l}-0.246 \\
(1.83)\end{array}$ & $\begin{array}{l}-0.178 \\
(1.25)\end{array}$ & $\begin{array}{l}-0.315 \\
(2.14)\end{array}$ & $\begin{array}{r}-0.650 \\
(4.36)\end{array}$ & $\begin{array}{l}-0.484 \\
(2.97)\end{array}$ & $\begin{array}{l}-0.550 \\
(3.25)\end{array}$ \\
\hline $\operatorname{KIDS}^{(\mathrm{e})}$ & $\begin{array}{l}-0.035 \\
(0.38)\end{array}$ & $\begin{array}{l}-0.123 \\
(1.31)\end{array}$ & $\begin{array}{l}-0.051 \\
(0.51)\end{array}$ & $\begin{array}{l}-0.262 \\
(2.60)\end{array}$ & $\begin{array}{l}-0.220 \\
(2.07)\end{array}$ & $\begin{array}{l}-0.232 \\
(1.99)\end{array}$ \\
\hline $\operatorname{MUR}^{(\mathrm{f})}$ & $\begin{array}{l}0.088 \\
(0.47)\end{array}$ & $\begin{array}{l}0.047 \\
(0.25)\end{array}$ & $\begin{array}{l}0.141 \\
(0.71)\end{array}$ & $\begin{array}{l}0.113 \\
(0.44)\end{array}$ & $\begin{array}{l}-0.338 \\
(1.29)\end{array}$ & $\begin{array}{c}-0.366 \\
(1.37)\end{array}$ \\
\hline
\end{tabular}




\begin{tabular}{lccc|ccc}
$\mathrm{OR}^{(\mathrm{g})}$ & -0.023 & -0.002 & 0.059 & -0.576 & -0.555 & -0.560 \\
& $(0.27)$ & $(0.03)$ & $(0.65)$ & $(6.11)$ & $(5.46)$ & $(5.20)$ \\
$\chi^{2}$ & 941.99 & 1013.34 & 1114.22 & 803.64 & 957.17 & 1102.54 \\
$\begin{array}{l}\text { Prediction success } \\
\text { rate (\%) }\end{array}$ & 78.11 & 77.59 & 79.21 & 79.99 & 80.25 & 81.88 \\
Sample size $^{(\mathrm{h})}$ & 1919 & 1919 & 1919 & 1499 & 1499 & 1499 \\
\hline
\end{tabular}

Note: Numbers in parentheses are ' $\mathrm{t}$ ' statistics.

(a) Variable not entered.

(b) ENS denotes Employer Nomination Scheme.

${ }^{\text {(c) }}$ Whether a spouse who was part of the migrating unit is present in the household.

(d) Whether a spouse who was not part of the migrating unit is present in the household.

(e) Whether children in the household.

(f) Whether other relatives who gained approval to migrate to Australia as part of the Principal Applicant's migration application are present in the household.

${ }^{(g)}$ Whether other relatives are present in the household.

(h) The total number of males is 1919 . These data are weighted using sample weights to reflect a population of 24086 . The total number of females is 1499 . The data for females are weighted using sample weights to reflect a population of 24377.

The benchmark group defined by the omitted categorical variables is immigrants from Southern Europe who entered Australia under Independent visas, did not report cross country/culture in the former home country, did not visit Australia prior to migration, chose their initial State settled for reasons other than Family/Friends, did not have post-immigration contact with ethnic agencies and do not expect to leave Australia.

Source: Longitudinal Survey of Immigrants to Australia (Wave One) 


\section{APPENDIX C}

TABLE C1: Bivariate Probit Model of English Speaking Skills, 15-64 Year Old Males and Females from Non-English Speaking Countries

\begin{tabular}{|c|c|c|c|c|c|c|}
\hline Variable & Wave 1 & Wave 2 & Wave 2 & Wave 3 & Wave 1 & Wave 3 \\
\hline Constant & $\begin{array}{l}-0.512 \\
(0.74)\end{array}$ & $\begin{array}{l}1.684 \\
(2.57)\end{array}$ & $\begin{array}{l}1.824 \\
(2.75)\end{array}$ & $\begin{array}{l}1.887 \\
(2.75)\end{array}$ & $\begin{array}{l}-0.584 \\
(0.82)\end{array}$ & $\begin{array}{l}1.824 \\
(2.72)\end{array}$ \\
\hline \multicolumn{7}{|l|}{ Visa Category } \\
\hline $\begin{array}{l}\text { Humanitarian } \\
\text { (Refugee) }\end{array}$ & $\begin{array}{l}-0.536 \\
(3.90)\end{array}$ & $\begin{array}{l}-0.279 \\
(2.05)\end{array}$ & $\begin{array}{l}-0.183 \\
(1.35)\end{array}$ & $\begin{array}{l}-0.097 \\
(0.71)\end{array}$ & $\begin{array}{l}-0.584 \\
(4.25)\end{array}$ & $\begin{array}{r}-0.139 \\
(1.03)\end{array}$ \\
\hline $\begin{array}{l}\text { Preferential } \\
\text { Family }\end{array}$ & $\begin{array}{l}-0.393 \\
(3.69)\end{array}$ & $\begin{array}{l}-0.234 \\
(2.11)\end{array}$ & $\begin{array}{l}-0.207 \\
(1.90)\end{array}$ & $\begin{array}{l}-0.222 \\
(2.02)\end{array}$ & $\begin{array}{l}-0.403 \\
(3.87)\end{array}$ & $\begin{array}{r}-0.248 \\
(2.22)\end{array}$ \\
\hline $\begin{array}{l}\text { Concessional } \\
\text { Family }\end{array}$ & $\begin{array}{l}-0.475 \\
(3.78)\end{array}$ & $\begin{array}{r}-0.314 \\
(2.45)\end{array}$ & $\begin{array}{l}-0.261 \\
(2.03)\end{array}$ & $\begin{array}{l}-0.179 \\
(1.38)\end{array}$ & $\begin{array}{l}-0.455 \\
(3.54)\end{array}$ & $\begin{array}{c}-0.204 \\
(1.57)\end{array}$ \\
\hline $\begin{array}{l}\text { Business } \\
\text { Skills/ENS }\end{array}$ & $\begin{array}{l}-0.414 \\
(1.88)\end{array}$ & $\begin{array}{l}-0.512 \\
(2.36)\end{array}$ & $\begin{array}{l}-0.471 \\
(2.26)\end{array}$ & $\begin{array}{l}-0.259 \\
(1.19)\end{array}$ & $\begin{array}{l}-0.445 \\
(2.06)\end{array}$ & $\begin{array}{r}-0.302 \\
(1.37)\end{array}$ \\
\hline $\begin{array}{l}\text { Age at } \\
\text { migration }\end{array}$ & $\begin{array}{l}-0.011 \\
(3.32)\end{array}$ & $\begin{array}{r}-0.025 \\
(7.48)\end{array}$ & $\begin{array}{l}-0.028 \\
(8.57)\end{array}$ & $\begin{array}{l}-0.037 \\
(10.80)\end{array}$ & $\begin{array}{l}-0.011 \\
(3.30)\end{array}$ & $\begin{array}{l}-0.035 \\
(10.05)\end{array}$ \\
\hline Education & $\begin{array}{c}0.126 \\
(11.55)\end{array}$ & $\begin{array}{c}0.107 \\
(10.69)\end{array}$ & $\begin{array}{c}0.105 \\
(14.46)\end{array}$ & $\begin{array}{c}0.108 \\
(10.85)\end{array}$ & $\begin{array}{c}0.127 \\
(11.55)\end{array}$ & $\begin{array}{c}0.108 \\
(10.65)\end{array}$ \\
\hline Female & $\begin{array}{l}-0.094 \\
(1.35)\end{array}$ & $\begin{array}{r}-0.090 \\
(1.33)\end{array}$ & $\begin{array}{l}-0.082 \\
(1.23)\end{array}$ & $\begin{array}{l}-0.223 \\
(3.33)\end{array}$ & $\begin{array}{l}-0.081 \\
(1.19)\end{array}$ & $\begin{array}{l}-0.238 \\
(3.56)\end{array}$ \\
\hline $\begin{array}{l}\text { Former British } \\
\text { colony }\end{array}$ & $\begin{array}{l}0.915 \\
(8.30)\end{array}$ & $\begin{array}{l}0.671 \\
(6.45)\end{array}$ & $\begin{array}{l}0.661 \\
(6.36)\end{array}$ & $\begin{array}{l}0.469 \\
(4.44)\end{array}$ & $\begin{array}{l}0.821 \\
(7.45)\end{array}$ & $\begin{array}{l}0.402 \\
(3.78)\end{array}$ \\
\hline $\begin{array}{l}\text { Cross } \\
\text { country/culture } \\
\text { contact in } \\
\text { former home } \\
\text { country }\end{array}$ & $\begin{array}{l}0.160 \\
(2.50)\end{array}$ & $\begin{array}{l}0.070 \\
(1.11)\end{array}$ & $\begin{array}{l}0.097 \\
(1.52)\end{array}$ & $\begin{array}{l}0.103 \\
(1.61)\end{array}$ & $\begin{array}{l}0.189 \\
(2.91)\end{array}$ & $\begin{array}{l}0.098 \\
(1.51)\end{array}$ \\
\hline $\begin{array}{l}\text { PA visited } \\
\text { Australia }\end{array}$ & $\begin{array}{l}0.172 \\
(2.30)\end{array}$ & $\begin{array}{l}0.117 \\
(1.59)\end{array}$ & $\begin{array}{l}0.160 \\
(2.15)\end{array}$ & $\begin{array}{c}-0.064 \\
(0.80)\end{array}$ & $\begin{array}{l}0.199 \\
(2.66)\end{array}$ & $\begin{array}{c}-0.064 \\
(0.80)\end{array}$ \\
\hline $\begin{array}{l}\text { Main reason } \\
\text { for choosing } \\
\text { State settled } \\
\text { was } \\
\text { Family/Friends }\end{array}$ & $\begin{array}{l}-0.088 \\
(1.02)\end{array}$ & $\begin{array}{r}-0.017 \\
(0.21)\end{array}$ & $\begin{array}{l}-0.015 \\
(0.18)\end{array}$ & $\begin{array}{l}-0.011 \\
(0.12)\end{array}$ & $\begin{array}{l}-0.063 \\
(0.74)\end{array}$ & $\begin{array}{r}-0.029 \\
(0.34)\end{array}$ \\
\hline $\begin{array}{l}\text { Contact with } \\
\text { ethnic agencies }\end{array}$ & $\begin{array}{l}-0.109 \\
(1.87)\end{array}$ & $\begin{array}{l}0.025 \\
(0.20)\end{array}$ & $\begin{array}{l}-0.107 \\
(0.75)\end{array}$ & $\begin{array}{l}0.102 \\
(0.48)\end{array}$ & $\begin{array}{l}-0.075 \\
(1.14)\end{array}$ & $\begin{array}{l}0.012 \\
(0.05)\end{array}$ \\
\hline
\end{tabular}




\begin{tabular}{|c|c|c|c|c|c|c|}
\hline $\begin{array}{l}\text { Expect to leave } \\
\text { Australia }\end{array}$ & $\begin{array}{r}-0.122 \\
(0.94)\end{array}$ & $\begin{array}{l}0.107 \\
(0.66)\end{array}$ & $\begin{array}{l}0.352 \\
(2.85)\end{array}$ & $\begin{array}{l}0.213 \\
(1.45)\end{array}$ & $\begin{array}{l}-0.221 \\
(1.59)\end{array}$ & $\begin{array}{l}0.209 \\
(1.25)\end{array}$ \\
\hline $\begin{array}{l}\text { Birthplace } \\
\text { concentration }\end{array}$ & $\begin{array}{r}-0.012 \\
(1.36)\end{array}$ & $\begin{array}{l}0.008 \\
(1.01)\end{array}$ & $\begin{array}{l}-0.008 \\
(1.23)\end{array}$ & $\begin{array}{l}-0.014 \\
(1.74)\end{array}$ & $\begin{array}{l}0.001 \\
(0.15)\end{array}$ & $\begin{array}{l}-0.023 \\
(2.74)\end{array}$ \\
\hline Distance/1000 & $\begin{array}{l}0.067 \\
(0.66)\end{array}$ & $\begin{array}{l}-0.047 \\
(0.50)\end{array}$ & $\begin{array}{l}-0.057 \\
(0.58)\end{array}$ & $\begin{array}{l}-0.100 \\
(1.02)\end{array}$ & $\begin{array}{l}0.040 \\
(0.38)\end{array}$ & $\begin{array}{l}-0.093 \\
(0.97)\end{array}$ \\
\hline Distance $^{2} / 1 \mathrm{~m}$ & $\begin{array}{l}-0.006 \\
(1.10)\end{array}$ & $\begin{array}{l}-0.003 \\
(0.65)\end{array}$ & $\begin{array}{l}-0.003 \\
(0.58)\end{array}$ & $\begin{array}{l}0.002 \\
(0.42)\end{array}$ & $\begin{array}{l}-0.004 \\
(0.71)\end{array}$ & $\begin{array}{l}0.002 \\
(0.36)\end{array}$ \\
\hline $\begin{array}{l}\text { Linguistic } \\
\text { distance }\end{array}$ & $\begin{array}{l}-1.447 \\
(3.80)\end{array}$ & $\begin{array}{l}-1.030 \\
(2.73)\end{array}$ & $\begin{array}{l}-0.886 \\
(2.35)\end{array}$ & $\begin{array}{l}-1.145 \\
(2.93)\end{array}$ & $\begin{array}{l}-1.198 \\
(3.18)\end{array}$ & $\begin{array}{l}-1.080 \\
(2.84)\end{array}$ \\
\hline Family structure & & & & & & \\
\hline $\mathrm{KIDS}^{(\mathrm{b})}$ & $\begin{array}{l}-0.059 \\
(0.89)\end{array}$ & $\begin{array}{l}-0.101 \\
(1.68)\end{array}$ & $\begin{array}{l}-0.194 \\
(3.38)\end{array}$ & $\begin{array}{l}-0.089 \\
(1.46)\end{array}$ & $\begin{array}{l}-0.094 \\
(1.41)\end{array}$ & $\begin{array}{l}-0.098 \\
(1.59)\end{array}$ \\
\hline $\operatorname{MUR}^{(\mathrm{c})}$ & $\begin{array}{r}-0.240 \\
(1.66)\end{array}$ & $\begin{array}{l}0.056 \\
(0.33)\end{array}$ & $\begin{array}{l}-0.006 \\
(0.03)\end{array}$ & $\begin{array}{l}0.392 \\
(2.43)\end{array}$ & $\begin{array}{l}-0.018 \\
(0.10)\end{array}$ & $\begin{array}{l}0.389 \\
(2.22)\end{array}$ \\
\hline $\mathrm{OR}^{(\mathrm{d})}$ & $\begin{array}{c}-0.129 \\
(2.06)\end{array}$ & $\begin{array}{r}-0.125 \\
(2.04)\end{array}$ & $\begin{array}{l}-0.253 \\
(3.80)\end{array}$ & $\begin{array}{l}0.067 \\
(0.97)\end{array}$ & $\begin{array}{c}-0.152 \\
(2.30)\end{array}$ & $\begin{array}{l}0.125 \\
(1.88)\end{array}$ \\
\hline$\chi^{2}$ & \multicolumn{2}{|c|}{916.31} & \multicolumn{2}{|c|}{880.60} & \multicolumn{2}{|c|}{1122.06} \\
\hline $\begin{array}{l}\text { Prediction } \\
\text { success rate }(\%)\end{array}$ & \multicolumn{2}{|c|}{75.74} & \multicolumn{2}{|c|}{85.20} & \multicolumn{2}{|c|}{63.63} \\
\hline $\begin{array}{l}\text { Correlation } \\
\text { coefficient, } \rho\end{array}$ & \multicolumn{2}{|c|}{$\begin{array}{c}0.854 \\
(54.90)\end{array}$} & \multicolumn{2}{|c|}{$\begin{array}{c}0.790 \\
(41.00)\end{array}$} & \multicolumn{2}{|c|}{$\begin{array}{c}0.728 \\
(30.11)\end{array}$} \\
\hline Sample size $\mathrm{e}^{(\mathrm{e})}$ & \multicolumn{2}{|c|}{2304} & \multicolumn{2}{|c|}{2304} & \multicolumn{2}{|c|}{2304} \\
\hline
\end{tabular}

Note: Numbers in parentheses are 't' statistics. The specification of the model contains variables for 10 birthplace groups (namely, Western Europe, Northern Europe, Eastern Europe, the USSR and the Baltic States, the Middle East, North Africa, South East Asia, North East Asia, South Asia, and South and Central America.

${ }^{(a)}$ ENS denotes Employer Nomination Scheme.

${ }^{\text {(b) }}$ Whether children in the household.

${ }^{(c)}$ Whether other relatives who gained approval to migrate to Australia as part of the Principal Applicant's migration application are presented in the household.

${ }^{\text {(d) }}$ Whether other relatives are present in the household.

${ }^{\text {(e) }}$ The total number of cases is 2304 . The data are weighted using sample weight to reflect a population of 41060 .

The benchmark group defined by the omitted categorical variables is male immigrants from Southern Europe who entered Australia under Independent visas, did not report cross country/culture in the former home country, did not visit Australia prior to migration, chose their initial State settled for reasons other than Family/Friends, did not have post-immigration contact with ethnic agencies and do not expect to leave Australia.

Source: Longitudinal Survey of Immigrants to Australia (Wave One, Wave Two and Wave Three) 
TABLE C2: Single Equation Probit Model of English Speaking Skills, 15-64 Year Old Males and Females from Non-English Speaking Countries (corresponds to Bivariate Probit Models in Table C1)

\begin{tabular}{|c|c|c|c|c|c|c|}
\hline Variable & Wave 1 & Wave 2 & Wave 2 & Wave 3 & Wave 1 & Wave 3 \\
\hline Constant & $\begin{array}{l}-0.220 \\
(0.35)\end{array}$ & $\begin{array}{l}1.854 \\
(3.01)\end{array}$ & $\begin{array}{l}1.854 \\
(3.01)\end{array}$ & $\begin{array}{l}1.556 \\
(2.52)\end{array}$ & $\begin{array}{l}0.044 \\
(0.07)\end{array}$ & $\begin{array}{l}1.556 \\
(2.52)\end{array}$ \\
\hline Visa Category & & & & & & \\
\hline $\begin{array}{l}\text { Humanitarian } \\
\text { (Refugee) }\end{array}$ & $\begin{array}{l}-0.723 \\
(5.73)\end{array}$ & $\begin{array}{l}-0.347 \\
(2.83)\end{array}$ & $\begin{array}{l}-0.347 \\
(2.83)\end{array}$ & $\begin{array}{l}-0.233 \\
(1.86)\end{array}$ & $\begin{array}{l}-0.721 \\
(5.71)\end{array}$ & $\begin{array}{l}-0.233 \\
(1.86)\end{array}$ \\
\hline $\begin{array}{l}\text { Preferential } \\
\text { Family }\end{array}$ & $\begin{array}{l}-0.387 \\
(3.76)\end{array}$ & $\begin{array}{l}-0.282 \\
(2.72)\end{array}$ & $\begin{array}{l}-0.282 \\
(2.72)\end{array}$ & $\begin{array}{l}-0.212 \\
(1.99)\end{array}$ & $\begin{array}{l}-0.388 \\
(3.78)\end{array}$ & $\begin{array}{l}-0.212 \\
(1.99)\end{array}$ \\
\hline $\begin{array}{l}\text { Concessional } \\
\text { Family }\end{array}$ & $\begin{array}{l}-0.431 \\
(4.18)\end{array}$ & $\begin{array}{l}-0.333 \\
(3.23)\end{array}$ & $\begin{array}{l}-0.333 \\
(3.23)\end{array}$ & $\begin{array}{c}-0.186 \\
(1.76)\end{array}$ & $\begin{array}{l}-0.432 \\
(4.19)\end{array}$ & $\begin{array}{l}-0.186 \\
(1.76)\end{array}$ \\
\hline $\begin{array}{l}\text { Business } \\
\text { Skills/ENS }\end{array}$ & $\begin{array}{r}-0.460 \\
(3.25)\end{array}$ & $\begin{array}{l}-0.519 \\
(3.67)\end{array}$ & $\begin{array}{l}-0.519 \\
(3.67)\end{array}$ & $\begin{array}{l}-0.304 \\
(2.10)\end{array}$ & $\begin{array}{l}-0.467 \\
(3.30)\end{array}$ & $\begin{array}{l}-0.304 \\
(2.10)\end{array}$ \\
\hline $\begin{array}{l}\text { Age at } \\
\text { migration }\end{array}$ & $\begin{array}{r}-0.017 \\
(4.70)\end{array}$ & $\begin{array}{l}-0.029 \\
(8.71)\end{array}$ & $\begin{array}{l}-0.029 \\
(8.71)\end{array}$ & $\begin{array}{c}-0.038 \\
(11.36)\end{array}$ & $\begin{array}{l}-0.017 \\
(4.70)\end{array}$ & $\begin{array}{l}-0.038 \\
(11.36)\end{array}$ \\
\hline Education & $\begin{array}{c}0.132 \\
(11.98)\end{array}$ & $\begin{array}{c}0.112 \\
(10.95)\end{array}$ & $\begin{array}{c}0.112 \\
(10.95)\end{array}$ & $\begin{array}{c}0.115 \\
(11.29)\end{array}$ & $\begin{array}{c}0.132 \\
(11.97)\end{array}$ & $\begin{array}{c}0.115 \\
(11.29)\end{array}$ \\
\hline Female & $\begin{array}{l}-0.137 \\
(2.16)\end{array}$ & $\begin{array}{l}-0.162 \\
(2.62)\end{array}$ & $\begin{array}{l}-0.162 \\
(2.62)\end{array}$ & $\begin{array}{l}-0.172 \\
(2.76)\end{array}$ & $\begin{array}{l}-0.137 \\
(2.16)\end{array}$ & $\begin{array}{l}-0.172 \\
(2.76)\end{array}$ \\
\hline $\begin{array}{l}\text { Former British } \\
\text { colony }\end{array}$ & $\begin{array}{l}0.297 \\
(2.63)\end{array}$ & $\begin{array}{l}0.033 \\
(0.30)\end{array}$ & $\begin{array}{l}0.033 \\
(0.30)\end{array}$ & $\begin{array}{l}-0.071 \\
(0.63)\end{array}$ & $\begin{array}{l}0.281 \\
(2.47)\end{array}$ & $\begin{array}{r}-0.071 \\
(0.63)\end{array}$ \\
\hline $\begin{array}{l}\text { Cross } \\
\text { country/culture } \\
\text { contact in } \\
\text { former home } \\
\text { country }\end{array}$ & $\begin{array}{l}0.163 \\
(2.63)\end{array}$ & $\begin{array}{l}0.080 \\
(1.32)\end{array}$ & $\begin{array}{l}0.080 \\
(1.32)\end{array}$ & $\begin{array}{l}0.012 \\
(0.20)\end{array}$ & $\begin{array}{l}0.162 \\
(2.61)\end{array}$ & $\begin{array}{l}0.012 \\
(0.20)\end{array}$ \\
\hline $\begin{array}{l}\text { PA visited } \\
\text { Australia }\end{array}$ & $\begin{array}{l}0.111 \\
(1.53)\end{array}$ & $\begin{array}{l}-0.020 \\
(0.28)\end{array}$ & $\begin{array}{l}-0.020 \\
(0.28)\end{array}$ & $\begin{array}{c}-0.098 \\
(1.33)\end{array}$ & $\begin{array}{l}0.104 \\
(1.45)\end{array}$ & $\begin{array}{l}-0.098 \\
(1.33)\end{array}$ \\
\hline $\begin{array}{l}\text { Main reason } \\
\text { for choosing } \\
\text { State settled } \\
\text { was } \\
\text { Family/Friends }\end{array}$ & $\begin{array}{c}-0.048 \\
(0.60)\end{array}$ & $\begin{array}{l}-0.035 \\
(0.44)\end{array}$ & $\begin{array}{l}-0.035 \\
(0.44)\end{array}$ & $\begin{array}{l}-0.019 \\
(0.23)\end{array}$ & $\begin{array}{l}-0.050 \\
(0.61)\end{array}$ & $\begin{array}{l}-0.019 \\
(0.23)\end{array}$ \\
\hline $\begin{array}{l}\text { Contact with } \\
\text { ethnic agencies }\end{array}$ & $\begin{array}{r}-0.038 \\
(0.57)\end{array}$ & $\begin{array}{l}-0.164 \\
(1.06)\end{array}$ & $\begin{array}{r}-0.164 \\
(1.06)\end{array}$ & $\begin{array}{l}0.200 \\
(0.94)\end{array}$ & $\begin{array}{l}-0.038 \\
(0.58)\end{array}$ & $\begin{array}{l}0.200 \\
(0.94)\end{array}$ \\
\hline $\begin{array}{l}\text { Expect to leave } \\
\text { Australia }\end{array}$ & $\begin{array}{l}0.012 \\
(0.08)\end{array}$ & $\begin{array}{l}0.128 \\
(0.87)\end{array}$ & $\begin{array}{l}0.128 \\
(0.87)\end{array}$ & $\begin{array}{l}0.054 \\
(0.33)\end{array}$ & $\begin{array}{l}-0.012 \\
(0.08)\end{array}$ & $\begin{array}{l}0.054 \\
(0.33)\end{array}$ \\
\hline
\end{tabular}




\begin{tabular}{|c|c|c|c|c|c|c|}
\hline $\begin{array}{l}\text { Birthplace } \\
\text { concentration }\end{array}$ & $\begin{array}{l}-0.004 \\
(0.37)\end{array}$ & $\begin{array}{l}-0.017 \\
(1.77)\end{array}$ & $\begin{array}{r}-0.017 \\
(1.77)\end{array}$ & $\begin{array}{l}-0.014 \\
(1.55)\end{array}$ & $\begin{array}{l}-0.005 \\
(0.48)\end{array}$ & $\begin{array}{l}-0.014 \\
(1.55)\end{array}$ \\
\hline Distance/1000 & $\begin{array}{l}0.039 \\
(0.46)\end{array}$ & $\begin{array}{l}-0.140 \\
(1.65)\end{array}$ & $\begin{array}{r}-0.140 \\
(1.65)\end{array}$ & $\begin{array}{l}-0.097 \\
(1.16)\end{array}$ & $\begin{array}{l}-0.004 \\
(0.04)\end{array}$ & $\begin{array}{l}-0.097 \\
(1.16)\end{array}$ \\
\hline Distance $^{2} / 1 \mathrm{~m}$. & $\begin{array}{l}-0.005 \\
(1.24)\end{array}$ & $\begin{array}{l}-0.002 \\
(0.48)\end{array}$ & $\begin{array}{r}-0.002 \\
(0.48)\end{array}$ & $\begin{array}{l}0.003 \\
(0.67)\end{array}$ & $\begin{array}{l}-0.003 \\
(0.81)\end{array}$ & $\begin{array}{l}0.003 \\
(0.67)\end{array}$ \\
\hline $\begin{array}{l}\text { Linguistic } \\
\text { distance }\end{array}$ & $\begin{array}{l}-0.891 \\
(2.47)\end{array}$ & $\begin{array}{l}-0.590 \\
(1.67)\end{array}$ & $\begin{array}{r}-0.590 \\
(1.67)\end{array}$ & $\begin{array}{l}-0.640 \\
(1.80)\end{array}$ & $\begin{array}{l}-0.886 \\
(2.45)\end{array}$ & $\begin{array}{l}-0.640 \\
(1.80)\end{array}$ \\
\hline \multicolumn{7}{|l|}{ Family structure } \\
\hline $\operatorname{KIDS}^{(\mathrm{b})}$ & $\begin{array}{l}-0.020 \\
(0.30)\end{array}$ & $\begin{array}{c}-0.0885 \\
(1.47)\end{array}$ & $\begin{array}{c}-0.0885 \\
(1.47)\end{array}$ & $\begin{array}{l}-0.019 \\
(0.31)\end{array}$ & $\begin{array}{l}-0.020 \\
(0.30)\end{array}$ & $\begin{array}{l}-0.019 \\
(0.31)\end{array}$ \\
\hline MUR $^{(\mathrm{c})}$ & $\begin{array}{l}-0.079 \\
(0.40)\end{array}$ & $\begin{array}{l}0.001 \\
(0.00)\end{array}$ & $\begin{array}{l}0.001 \\
(0.00)\end{array}$ & $\begin{array}{l}0.076 \\
(0.37)\end{array}$ & $\begin{array}{l}0.081 \\
(0.41)\end{array}$ & $\begin{array}{l}0.076 \\
(0.37)\end{array}$ \\
\hline $\mathrm{OR}^{(\mathrm{d})}$ & $\begin{array}{l}-0.085 \\
(1.23)\end{array}$ & $\begin{array}{l}-0.031 \\
(0.42)\end{array}$ & $\begin{array}{r}-0.031 \\
(0.42)\end{array}$ & $\begin{array}{l}0.076 \\
(0.98)\end{array}$ & $\begin{array}{l}-0.083 \\
(1.20)\end{array}$ & $\begin{array}{l}0.076 \\
(0.98)\end{array}$ \\
\hline$\chi^{2}$ & 583.79 & 504.01 & 504.01 & 511.26 & 584.48 & 511.26 \\
\hline $\begin{array}{l}\text { Prediction } \\
\text { success rate (\%) }\end{array}$ & 71.66 & 70.18 & 70.18 & 71.05 & 71.48 & 71.05 \\
\hline Sample size $\mathrm{e}^{(\mathrm{e})}$ & \multicolumn{2}{|c|}{2304} & \multicolumn{2}{|c|}{2304} & \multicolumn{2}{|c|}{2304} \\
\hline
\end{tabular}

Note: Numbers in parentheses are ' $t$ ' statistics. The specification of the model contains variables for 10 birthplace groups (namely, Western Europe, Northern Europe, Eastern Europe, the USSR and the Baltic States, the Middle East, North Africa, South East Asia, North East Asia, South Asia, and South and Central America.

${ }^{(a)}$ ENS denotes Employer Nomination Scheme.

${ }^{(b)}$ Whether children in the household.

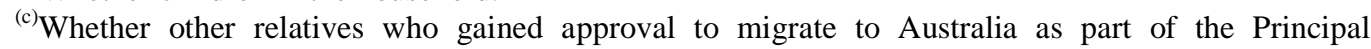
Applicant's migration application are presented in the household.

${ }^{(\mathrm{d})}$ Whether other relatives are present in the household.

${ }^{(\mathrm{e})}$ The total number of cases is 2304 . The data are weighted using sample weight to reflect a population of 41060 .

The benchmark group defined by the omitted categorical variables is male immigrants from Southern Europe who entered Australia under Independent visas, did not report cross country/culture in the former home country, did not visit Australia prior to migration, chose their initial State settled for reasons other than Family/Friends, did not have post-immigration contact with ethnic agencies and do not expect to leave Australia.

Source: Longitudinal Survey of Immigrants to Australia (Wave One, Wave Two and Wave Three) 


\section{IZA Discussion Papers}

No. Author(s)

486

A. L. Booth

M. L. Bryan

487

R. L. Lumsdaine

E. S. Prasad

488
A. Ciccone

G. Peri

489

490

W. F. Richter

J. T. Addison

L. Bellmann

C. Schnabel

J. Wagner

\section{P. Keane}

E. S. Prasad

D. Gatti

P. Frijters

J. P. Haisken-DeNew

M. A. Shields

G. A. Pfann

H. van Kranenburg

D. A. Jaeger

501

N. Rajah

A. van Soest
Title

Area

Date

Who pays for General Training? New Evidence

6

for British Men and Women

Identifying the Common Component of

International Economic Fluctuations:

A New Approach

Identifying Human Capital Externalities:

Theory with an Application to US Cities

1

04/02

Employment Patterns of Husbands and Wives

5

04/02

and Family Income Distribution in Italy (1977-

1998)

Social Security and Taxation of Labour Subject 2

05/02

to Subsidiarity and Freedom of Movement

On the Production of Victory: Empirical Deter-

minants of Battlefield Success in Modern War

Benefit Entitlement and Unemployment

Duration: The Role of Policy Endogeneity

Work-Related Stress, Quitting Intentions and

Absenteeism

The Role of the Regional Milieu for the Decision

to Start a New Firm: Empirical Evidence for

Germany

German Works Councils Old and New:

3

$05 / 02$

Incidence, Coverage and Determinants

Changes in the Structure of Earnings During the 4

Polish Transition

European Integration and Employment:

A New Role for Active Fiscal Policies?

Individual Rationality and Learning: Welfare

6

05/02

Expectations in East Germany Post-

Reunification

Tax Policy, Location Choices, and Market

6

$05 / 02$

Structure

Estimating the Returns to Education Using the Newest Current Population Survey Education Questions

Class Size, Education, and Wages

B. R. Chiswick

Y. L. Lee

P. W. Miller

\section{4/02}

$4 / 02$

05/02

05/02

05/02

05/02

05/02

05/02

05/02

Experience in a Longitudinal Survey 